\title{
Rewiew of the subgenus Smaragdula Pesarini \& Sabbadini, 2004, and two new species from Turkey (Coleoptera: Cerambycidae: Laminae, Agapanthiini)
}

\author{
KAREL HODEK
}

Havlenova 29, 639 00, Brno - Štýřice, Czech Republic; e-mail: hkarlos@seznam.cz

Hodek, K.: Rewiew of the subgenus Smaragdula Pesarini \& Sabbadini, 2004, and two new species from Turkey (Coleoptera: Cerambycidae: Laminae, Agapanthiini).

Abstract: In the present contribution, the author summarizes his knowledge concerning the subgenus Smaragdula supplemented by a key to species and two new species of the subgenus Smaragdula Pesarini \& Sabbadini, 2004, Agapanthiini Audinet-Serville, 1835. The two new species come from Turkey. Both of them, Agapanthia (Smaragdula) grosseri sp. nov. and Agapanthia (Smaragdula) kadleci sp. nov. perfectly fall into the homogeneous subgenus Smaragdula as to their habitus. Agapanthia (Smaragdula) grosseri sp. nov. is similar to the species Agapanthia (Smaragdula) chylybaea. Agapanthia (Smaragdula) kadleci sp. nov. resembles the species Agapanthia (Smaragdula) lais. The comparative analysis presented below describes the differentiation of the two new species from other species of the subgenus. The text of the contribution is supplemented by appropriate photographs.

Keywords: Taxonomy, description, new species, key, Coleoptera, Cerambycidae, Lamiinae, Agapanthia, Smaragdula, Turkey

\section{Introduction}

Within the framework of the tribe Agapanthiini, 96 genera comprising 740 species (Tavakilian \& Chevillotte 2020) are currently known. The Palaearctic Region is inhabited by 80 genera (DANILEVSKY 2021), the most numerous genus being Agapanthia Audinet-Serville, 1835 including 10 subgenera. One of them is the subgenus Smaragdula established by Pesarini \& SABBADINI (2004). This subgenus currently comprises 20 species, the westernmost occurrence is known from Spain and Portugal and the furthermore occurrence continues over the whole south and central Europe eastward to Central Asian Kyrgyzstan and a part of Siberia. In the southward direction, representatives of the group reach Israel and Jordan. The area of Turkey appears to be the centre of the occurrence, from which the highest number of species have still been described (DANILEVSKY 2021).

The subgenus Smaragdula is a considerably homogeneous group including more or less similar species sharing peculiar metallic bright colour of the whole body, i. e. of both dorsal and ventral sides including legs and antennae. The body is elongate, cylindrical, only in $A$. (S.) rapuzzii Hodek \& Tichý, 2021 it is rather short and flat. The head scapus, pronotum and elytra exert characteristic punctation. The punctation density and system, particularly those on the pronotum, are characters important for particular taxa. A further 
distinct feature of the group is the body pubescence consisting of rather long, erect setae and short decumbent ones. The longer setae are black or dark brown, sparse and more or less erect. Two types of the decumbent pubescence are present - dark and light. The light (white, greyish white or yellowish) pubescence is usually distinct on the frons, genae, and on pronotum typically arranged in two or three longitudinal stripes (central stripe runs through the middle, two lateral stripes are present on sides). The stripes - particularly the central one - may be more or less reduced. The elytra are mostly covered with light and dark pubescence, the light one being usually more distinct in the apical half. In almost all taxa in this group, the elytral punctation indicates two more or less distinct longitudinal ribs on each side. All the three pairs of legs including tarsi and the body underside are usually equipped with yellow pubescence. However, antennae with a dark decumbent pubescence and with longer setae on the inner side, have rather more frequently white to pale grey pubescence from antennomere 3, typically arranged in pale circles.

Given the fact that in terms of phylogeny the group is young, the orientation in the group Smaragdula can be rather complicated since most identification characters have not yet been stabilized. This particularly concerns the shape variability of male genitals, where even individuals from one location can exert considerable differences in the shape of parameres (stronger/weaker curvature angle), and/or in the aedeagus - sides straight in the apical third with more or less distinct sinuation (Fig. 10). A similar problem is also known in certain taxa of the group Phytoecia. Due to this, in my opinions, the shape of copulatory organs can be considered as an auxiliary rather than primary identification character. The problem is similar in the shape of the pronotum, which is considerably variable in most taxa of the group in the dorsal view. Larger and well developed individuals have usually the pronotum conspicuously widened on sides, (the pronotum is transversal or square-shaped, with moderately coarser sculpture) and smaller individuals of the same taxon have the pronotum slightly widened only on sides (the pronotum is longitudinal). Representatives of two different taxa can be seemingly considered in the case of these limit parameters (Fig. 9). But even in the case of these limit parameters, the pronotum punctation remains the same and typical for the taxon. As already mentioned above, there is a variable body pubescence, which can be very dense in some individuals and missing in some others. This is particularly the case of the pale pubescence of the head, pronotum and antennae, but also of legs, thorax and abdomen. In contrast, the variability of the elytral pubescence is usually not so distinct. The sexual dimorphism is not very differentiated in the group. There are differences in the length of antennae, which are longer in males compared to females; the elytra width at humeri are sometimes wider in females compared to males.

As to the bionomics, the species of the group Smaragdula are monophagous to oligophagous, seldom polyphagous. The species can be divided according to host plants into three basic groups as follows. In the first group, the development depends on different species of the family Fabacea (Astralagus sp., Psoralea bitumonosa, Onobrychis, Erophaca baetica orientalis); the group includes the following taxa: $A$. (S.) pesarini Sama \& Rapuzzi 2010, A. (S.) amitina Holzschuh, 1989, A. (S.) psoraleae Sama \& Rapuzzi, 2010, A. (S.) izzilloi Rapuzzi, Sama \& Kotán, 2013, A. (S.) naciyae Rapuzzi \& Sama, 2012, and $A$. (S.) petranyi Kotán, 2014. In the second group, the development is associated with species of the family Dipsacaceae, particularly with the genera Knautia, Cephalaria, and Dipsacus; it includes the following taxa: A. (S.) frivaldszkyi Ganglbauer, 1884, A. (S.) intermedia Ganglbauer, 1884, A. (S.) osmanlis Reiche \& Saulcy, 1858, and A. (S.) ozdikmeni Rapuzzi \& Sama, 2012. The third group is associated with plants of 
the family Asteraceae. It includes the following species: A. (S.) lais Reiche \& Saulcy, 1858, A. (S.) viti Rapuzzi \& Sama, 2012, and A. (S.) chalybaea Faldermann 1837. The species, $A$. (S.) rapuzzii Hodek \& Tichý, 2021 whose imagines were found on a plant from the genus Prangos (Apiaceae) and $A$. (S.) posti Hodek \& Tichý, 2021, which was found on a plant from the genus Valeriana (Caprifoliaceae) seem to be exceptional. Polyphagous species are contrastingly $A$. (S.) violacea Fabricius, 1775 and obviously also $A$. (S.) persicola Reitter, 1894.

Mature imagines of the subgenus Smaragdula search for host plants, on which they are also dwelling. Larvae are developed in above-ground parts of plant stalks. The development typically takes a period of one year.

\section{Material and methods}

During the study of the subgenus Smaragdula, more than 2500 specimens from private and institutional collections were examined. A proportion of this material is specified in the text. In some material, it was impossible to present all the data; this particularly concerns the extensive material from the National Museum in Prague.

In the compilation of the key, I attempted to avoid too variable characters, which could be rather misleading in the identification. The key is supplemented by photographs of pronota of certain taxa. It is furthermore supplemented by photographs of imagine habitus and details of body parts (head and male copulatory organs). The work presented here cannot include all cases of the variability, which also is beyond its scope, but the key below should facilitate the identification work.

Type and additional materials are deposited in the collections as follows:

NMP - collection of Národní Museum Praha, Czech Republic

NMW - collection of Naturhistorisches Museum Wien, Austria

TAU - collection of Tel Aviv University, Israel

DN - private collection of David Navrátil, Litomyšl, Czech Republic

JCH - private collection of Jiří Chvalkovský, Bořetín, Czech Republic

JK - private collection of Josef Kadlec, Varnsdorf, Czech Republic

$\mathrm{KH}$ - private collection of Karel Hodek, Brno, Czech Republic

LH - private collection of Lubomír Havlík, Polička, Czech Republic

LK - private collection of Ladislav Klapka, Česká Lípa, Czech Republic

LS - private collection of Lukáš Skořepa, Dačice, Czech Republic

MČ - private collection of Matěj Čermák, Praha, Czech Republic

MD - private collection of Mikhail Danilevsky, Moscow, Russia

$\mathrm{OK}$ - private collection of Ondřej Konvička, Vsetín, Czech Republic

OS - private collection of Ondřej Sabol, Ostrava-Nová Bělá, Czech Republic

PJ - private collection of Pavel Jelínek, Brno, Czech Republic

PK - private collection of Petr Kabátek, Praha, Czech Republic

PR - private collection of Pierpaolo Rapuzzi, Prepotto, Italy

PŠ - private collection of Pavel Štěpánek, Kladno, Czech Republic

TL - private collection of Tomáš Lengál, Olomouc, Czech Republic

TP - private collection of Tomáš Peterka, Veselí nad Lužnicí, Czech Republic

TT - private collection of Tomáš Tichý, Ostrava, Czech Republic

VS - private collection of Vladimír Skoupý, Kamenné Žehrovice, Czech Republic

WG - private collection of Walter Grosser, Opava, Czech Republic

ZK - private collection of Zdeněk Košt’ál, Pardubice, Czech Republic 
List of geographical abbreviations:

AB - Azerbaijan, AL - Albania, AR - Armenia, AU - Austria, BE - Belgium, BU - Bulgaria, CT - Russia: Central European Territory, CR - Croatia, CY - Cyprus, CZ - Czech, ES - Spain, FR - France, GE - Germany, GG - Georgia, GR - Greece , HU - Hungary, IN - Iran, IQ - Iraq, IS - Israel, IT - Italy, JO - Jordan, KI Kyrgyzstan, KZ - Kazakhstan, LA - Latvia, LE - Lebanon, LU - Luxembourg, MC - Macedonia, MD Moldavia, NT - Russia: North European Territory, PL - Poland, PT - Portugal, RO - Romania, SB - Serbia, SK - Slovakia, SL - Slovenia, SP - Spain, ST - Russia: South European Territory, SY - Syria, SZ Switzerland, TD - Tajikistan, TR - Turkey, UK - Ukraine, TM - Turkmenistan, UZ - Uzbekistan.

List of other abbreviations used:

HT - holotype; PT - paratype; ST - syntype

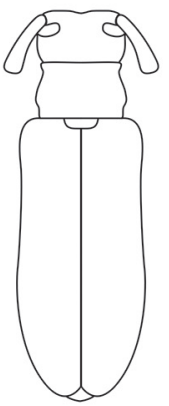

1
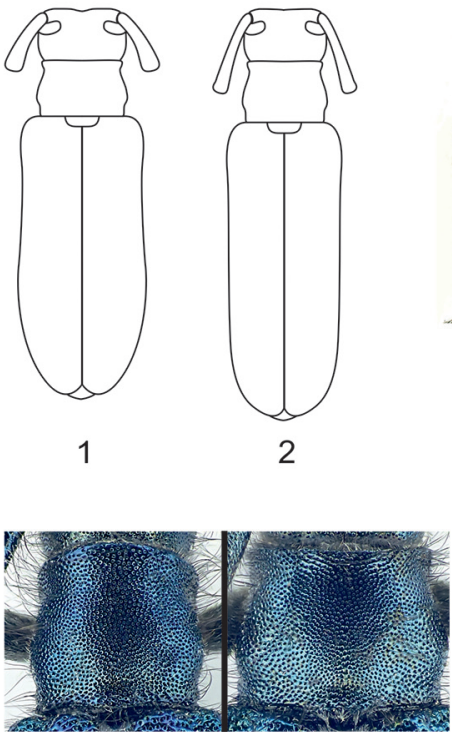

9

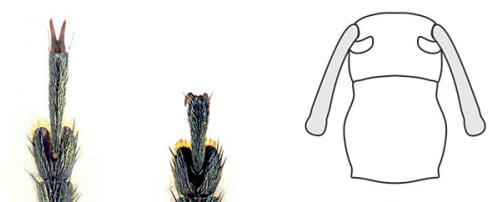

5

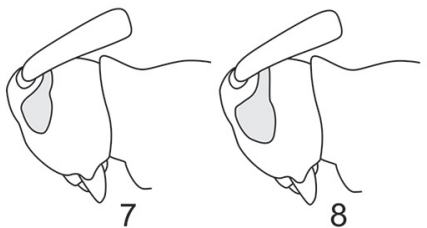

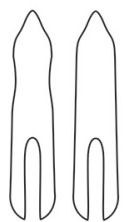

10

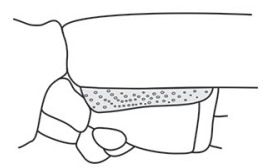

11

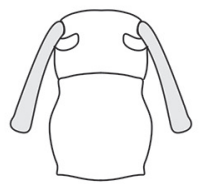

6

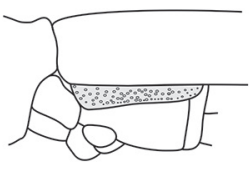

12

Figs 1-12: Details for the determination key

\section{Key Smaragdula}

1 - Elytra only with black pubescence, without pale tomentum 2

- Elytra with distinct pale as well as black pubescence

2 - Body short and flat (Fig. 1)

A. (S.) rapuzzii

- Body not flat, more or less uniformly elongate (Fig. 2) 3

3 - Elytra with sparse, more or less erect and long black setae A. (S.) frivaldszky - Elytra with both decumbent pubescence and erect setae

4 - Whole body conspicuously unicolour - rich jacinth blue

- Body usually with various metallic tinges, sometimes only more or less black...... 5 
5 - Pronotal punctures fine and unifom, without forming wrinkles 6

- Pronotal punctures coarser, with more or less distinct wrinkles in some places 7

6 - Antennae from 3rd antennomere white ringed, antennae in males exceeding elytra by 6 antennomeres; taxon known only from Peloponnesus (GR).... A. (S.) izzilloi - Antennal segments from antennomere 3 onwards entirely with light pubescence or only dark, rarely lightly ringed, antennae in males exceeding elytra 5 antennomeres

A. (S.) violacea

7 - Antennomeres 3-10 without metallic lustre, only antennomere 3 with weakly indicated metallic lustre. A. (S.) grosseri sp. nov.

- Antennae from antennomere 3 with distinct metallic lustre 8

8 - Whole elytra equipped with rather long, erect, black se. A. (S.) gemela - Elytra with rather long setae only in anterior half. A. (S.) kadleci sp. nov.

9 - Pronotal punctation fine and unifom, without forming wrinkles 10

- Pronotal punctures coarser, with more or less distinct wrinkles in some places ...... 11

10 - Elytra with white pubescence only in posterior third A. (S.) persicola - Elytra with dense white pubescence almost throughout A. (S.) intermedia

11 - Pronotum with more or less distinct stripes of pale tomentum on sides and disc ....... 12 - Pronotum without stripes of pale tomentum .............................................. 15

12 - Elytra with dense yellowish pubescence, antennae from antennomere 3 with narrow circles of pale tomentum only at base ........................................A. (S.) vitti - Antennae from antennomere 3 with wide circles of pale tomentum .................. 13 13 - Body unicolour bright blue, elytra with very fine white pubescence only in posterior half. A. (S.) ozdikmeni - Body typically with various metallic shades, white pubescence also present in anterior half of elytra............................................................... 14

14 - Basal half of elytra with rather long erect setae, male pronotum with coarse punctures forming fin wrinkle in some places.

A. (S.) chalybaea - Basal third of elytra with rather long erect setae, pronotum with uniform punctures not forming wrinkles

A. (S.) osmanlis

15 - Scutellum smooth throughout, distinctly bright, impunctate, glabrous ... A. (S.) nacyiae - Scutellum with more or less distinct punctation and pubescence, sometimes with very fine punctures and thin setae on sides, with shining and smooth central area ......... 16

16 - Scutellum with fine punctures and setae only on sides, smooth and shining in central area; in dorsal view, protarsomere 4 longer than protarsomeres 2 and 3 combined (Fig. 3) ........................................................................... petranyi - Scutellum with more or less distinct punctation, if scutellum is prevalently shining, then protarsomere 4 is shorter than or as long as protarsomeres 2 and 3 combined in dorsal view (Fig. 4) ....................................................... 17

17 - Whole body with distinct, long, erect, black setae A. (S.) amitina

- Elytra in posterior third without long, erect, black setae 18

18 - Antennae with pale circles from antennomere 4. A. (S.) lais - Antennae free of pale circles produced by pubescence 
19 - Species from areas of Near East to Transcaucasia

- Species from areas of Central Asia (KZ KG UZ)

20 - Scapus typically throttled before end, body relatively more robust and more shining, species known from LE IS (Fig. 5) A. (S.) psoraleae - Scapus typically only slightly throttled on outer side, body narrower and more elongate, species known from TR AR GG ( Fig. 6)

A. (S.) pesarini

21 - Eyes larger, inferior eye lobe as long as or only slightly longer than tempora; antennae sometime brown from antennomere 3 (Fig. 7)

A. (S.) incerta

- Eyes smaller, inferior eye lobe shorter than tempora, antennae black from antennomere 3 (Fig. 8)

A. (S.) talassica

\section{Taxonomy}

Tribe Agapanthiini Mulsant, 1839

Genus Agapanthia Audinet-Serville, 1835

Subgenus Smaragdula Pesarini et Sabbadini, 2004

Type species: Saperda violacea Fabricius, 1775

Agapanthia (Smaragdula) amitina Holzschuh, 1989

(Figs.: 11, 13, 35, 57, 79)

amitina Holzschuh, 1989: 174, Type locality: Iran, Zentralprovinz, 35 km NW Ghazvin, 1500 m,19.-21.V. 1976.

Geographic distribution: IR.

Material examined: 1 ex. PT - Iran, Zentralprovincz, 35 km NW Ghazvin, 19.- 21.V.1976 (ZK); 4 ex. - Iran, 64 km NE Minudasht, 1006 m, p. Khorásán, 19-20.V.2003 (PK); 7 ex. - Iran, Qazvin prov.,4 km W Kouhin, 1500 m, 24.5.2018, type locality (KH); 15 ex. - Iran, West Azerbaijan prov., $11 \mathrm{~km}$ SE of Serow, $1950 \mathrm{~m}$, 27.-28.5.2019 (KH); 9 ex. - Iran, West Azerbaijan prov., $11 \mathrm{~km}$ SE of Serow, $1950 \mathrm{~m}$, 30.-31.5.2018 (KH); 17 ex. - Iran, Qazvin prov.,4 km W Kouhin, 1500 m, 31.5.2012, type locality (KH).

A smaller species (6-11 mm), colour variable, yellowish green, green, blue to blackish brown, very similar to $A$. (S.) pesarini. Pronotum with dense punctures, sometimes forming indicated wrinkles at basal and apical margins. White stripes sometimes indicated on pronotum. Antennae with very weak pale pubescence without forming rings or only apical ends of dark antennomeres. Scutellum with more or less dense white pubescence. Elytra parallel, with rounded apex, densely punctate, without wrinkles, apically with weak white pubescence, with long, erect, black setae throughly.

Remarks: From a similar species $A$. (S.) pesarini, it can be well differentiated, particularly based on the presence of long, erect, black setae covering the whole body but being sparser than in the apical half of the elytra. In $A$. (S.) pesarini, the long erect setae in the posterior third of elytra are absent. A further differentiating character is the appearance of the episternum punctation. It is nearly regular in $A$. (S.) amitina (Fig. 11) whereas in $A$. (S.) pesarini, it is rather chaotically (irregularly) arranged (Fig. 12). 
Bionomics: Imagines can be found on Astralagus sp. (Fabaceae), which is also likely to be its host plant.

\section{Agapanthia (Smaragdula) chalybaea Faldermann, 1837}

(Figs.: 14, 36, 58,80, 81)

chalybea Villiers, 1967: 303, Type locality: Transcaucasia.

Geographic distribution: AB, AR, GG, IN, TR.

Material examined: 1 ex. - Armenia, Martuni 2 km W, 1520 m 5.VI.2016 (LK); 18 ex. - Armenia, 1,5 km OR Lichk, 31.V.2015 (KH); 11 ex. - SV Armenia, N. Tasthun,19.-22.6.2012 (PJ); 2 ex. - Armenia, Martuni, 13.6.2014 (TL); 1 ex. - Armenia, N Schvanidzor, 3.6.2013 (TL); 2 ex. - Armenia, N Tashtun, 18.6.2014 (TL); 3 ex. - Armenia, Lichk env., 31.5.2013 (TL).

Body length 10-17.5 mm. Colours variable, rather dark metallic green to green-blue, rarely even black with bronze lustre (Fig. 80). On pronotum with three stripes of pale pubescence, which can be more or less reduced or even quite missing. Pronotum with dense and moderately coarse punctation, which sparser at disc, at basal and apical margins forming wrinkles in males. Antenna with white pubescence from antennomere 3, antennomeres usually dark apically. Scutellum with dense, white pubescence. Elytra moderately narrowed towards apex, apex rounded. Elytra with dense punctuation not forming wrinkles, but sometimes forming two indicated longitudinal ribs on each side. Elytra densely pubescent, in basal half with long, erect, dark setae, whole area with moderately erect, white and black setae, white pubescence being denser than black one.

Remarks: Similar to A. (S.) osmanlis. Based on longer setae on elytra it can be recognised: in $A$. (S.) osmanlis, their length reaches about end of basal third; that of $A$. (S.) chalybaea is about end of basal half of elytra. In $A$. (S.) chalybaea, protarsomeres 2 and 3 combined are usually as long as or slightly longer than protarsomere 1 ; in $A$. (S.) osmanlis protarsomeres 2 and 3 combined are distinctly longer than basal protarsomere.

\section{Bionomics: On Cephalaria procera (Asteraceae).}

Agapanthia (Smaragdula) frivaldszkyi Ganglbauer, 1884

(Figs.: 15, 37, 59, 82, 83)

frivaldszkyi Ganglbauer, 1884: 546, Type locality: Kleinasien [Turkey].

Geographic distribution: BU, RO, IS, IN, IQ, JO, SY, TR.

Material examined: 4 ex. ST - serie (NMW); 1 ex. - Turkey, Elazig p., 4,5 km NE of Elazig, 23.5.2011 (LS); 1 ex. - Turkey, Mus p.,10 km E of Solhan, 30.5.2011 (LS); 1 ex. - Israel, Shoham, 30.III.2012 (TAU); 1 ex. - Israel, Qedumin 2-3 km N Nahal Te'enim, 300-400 m, 1.IV.2016 (TAU); 1 ex. - Israel, Hare Gilboa', Har Avinadav, 15.IV.2012 (TAU); 1 ex. - Israel, 'Lyyon, Nature Reserve, 1.V.2006 (TAU); 1 ex. - Israel, Qedumim, 1 km NNE Immam Ali Cenpotaph, 388-399 m, 25.III.2016 (TAU); 1 ex. - Israel, N Keziv, 6. IV.2001 (TAU); 1 ex. - Israel, Nave, Salom, 19.IV.1997 (TAU); 1 ex. - Turkey, Antakaya, 10.V.2000 (TAU); 1 ex. - Syria, Qala'at al-Hosn, E of Tartus, 450m, 19.IV.2007 (TT); 8 ex. - Turkey, Buglan gecidi, E of Solhan, Mus, 1600-1800m, 23.-24.VI.2009 (TT); 10 ex. - Iran, Kordestan prov., 3,5km E of Dezili, 1332 m, 26.V.2017 (DN); 28 ex. - Turkey, Mus, Buglan Gecidi pass, 23.06.2014 (WG); 4 ex. - Turkey, Mus, Buglan Gecidi pass, 24.06.2010 (WG); 8 ex. - Iran, Kurdistan p., 1 km E Dezli, 12.6.2016 (LS); 25 ex. - Iran, Kordestan prov., 
Dezli env.. 5.6.2018; 7 ex. - Iran, West Azerbaijan prov., 11 km SE of Serow, 1950 m, 27.-28.5.2019 (KH); 2 ex. - Turkey, Antalya pr., Alanya Boztepe, 11.-21.5.2005 (PJ); 23 ex. - Iran, Kordestan prov., Dezli env. 1300 m. 22.5.2019 (PJ); 1 ex. - Turkey, prov. Mus., 60 km NW Mus, 1629 m, Buglan Gec. 22.-42.6.2002 (TL); 38 ex. - Iran, Kordestan prov., 3.5 km E of Dezli, 26.5.2017 (TL).

Body length 6.5-13 mm. Imagines mostly dark blue, sometimes rather green to black, with violet tint. Some individuals with distinctly dark anterior half of body. Head very coarsely and deeply punctate. Scapus also with coarse to wrinkled punctation. Pronotum with coarse wrinkled punctation, which is sometimes sparser and without wrinkles in anterior half of body. Antennae with more or less white pubescence, without rings. Elytra with strong punctation, which is usually rather sparser at base, throughout pronotum and elytra area only with long, erect, black pubescence.

Remarks: For the species A. (S.) frivaldszkyi, the pubescence formed by long, erect, black setae without decumbent setae is typical. A further typical feature is in the distinctly coarse punctation of the head, pronotum and scapus. I know only individuals from a location in eastern Turkey having the pronotal punctation distinctly sparser. More numerous material will be necessary for further studies.

Bionomics: Imagines occur on Cephalaria speciosa, Cephalaria microcephala (Dipsacus) but probably also on further species of Cephalaria.

Agapanthia (Smaragdula) gemella Holzschuh, 1989

(Figs.: 16, 38, 60, 84)

gemella Holzschuh, 1989: 175, Type locality: Cypern, Prov. Limassol, Mandria, 1000 m, 20.IV.1980.

Geographic distribution: CY.

Material examined: 7 ex. - Cyprus, 15 km SSE Pomos, 26.3.2007 (LS); 1 ex. - Cyprus, Lemesos, Melini encv, III.2012 (KH); 1 ex. - Cyprus, Pano Panagia (Pafos), 1.IV.2017 (KH); 11 ex. - Cyprus, Alona env., 25 km N Lemesos, 3.4.2006 (WG); 11 ex. - Cyprus, Alona env. 25 km N Limassol, 1.-3.IV.2006 (PJ).

Body length 9-12 mm, colour most frequently yellow green with bronze tint, sometimes blueish green. Pronotum with dense punctation forming weak wrinkles in basal half. Antennae with weak greyish white pubescence, first three antennomeres with metallic lustre. Scutellum with punctation and white pubescence, sometimes almost entirely smooth and shining, only with individual thin hairlike setae present laterally. Elytra parallel, rounded on apex, with strong punctuation, sometimes forming weak transversal wrinkles in basal part, with dark, erect setae reduced in length from basal third towards apex.

Remarks: An endemic species known only from Cyprus.

Bionomics: Imagines are found on Erophaca baetica orientalis (Fabaceae).

Agapanthia (Smaragdula) grosseri sp. nov.

(Figs.: 17, 39, 61, 85, 86, 87, 88).

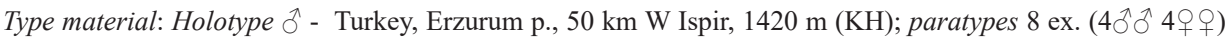

- Turkey, Erzurum p., 50 km W Ispir, 1420 (WG). 
Description: Body length 8.1-12.2 mm in males, 9.2-12.9 in females. Mostly bicolour, with metallic lustre, anterior half of body darker to matte black (without metallic lustre in last case).

Head slightly narrower than or as wide as pronotum with dense punctuation forming more or distinct central line on vertex. Head surface covered with sparse, long, erect black setae. Frons above labium with white tomentum forming two parallel stripes: the first, more distinct one runs from inferior side of eye to labium, second, less distinct one runs over genae. Palpi continuously pointed, black, sometimes with fine metallic lustre, distinctly paler only on apex. Antennae long, exceeding body by $25-30 \%$, only in males moderately longer compared to females. From third antennomere, antennae covered with very fine whitish tomentum giving impression of pale rings in first third or narrowly only at base. Scapus wrinkled-granulate, with very sparse, erect setae, antennomeres 3-5 also with rather long, erect setae on inner side. Antennae dark, first four antennomeres sometimes with metallic lustre. Scapus slightly throttled before end, its length corresponds to $4 / 5$ third antennonomere length.

Pronotum moderately longitudinal, throttled between anterior and posterior margins, distinctly convex behind anterior and posterior margins, but sometimes almost parallel, moderately widened only on sides. Pronotum as well as head surfaces very densely punctate, punctures mostly forming short and fine wrinkles at anterior as well as posterior margins (Fig. 17). Pronotum with sparse, long, erect, black setae. Scutellum rectangular, with unique, fine punctuation, more or less metallic, covered with fine, white tomentum.

Elytra moderately narrowing backwards, but sometimes rather parallel, finely convex behind humeri, rounded at end or with indicated obtuse angle. Elytral punctation very dense, rather coarse, particularly in anterior third, becoming considerably finer backwards. Punctation on elytra surface area leading in impression of rather indistinct transversal wrinkles. Elytral suture distinct throughout with exception of first 1/5. Elytra equipped with very sparse, erect, black setae, which shorter compared to pronotum. Longest setae present in first 1/3. Elytral area without whitish pubescence, but on elytral apex, exceeding whitish pubescence observed from ventral side. Elytral width at humeri corresponds to $1 / 4-1 / 3$ total elytral length. Ventral side, particularly abdominal ventrites, sparsely equipped with rather long, dark setae and rather fine, whitish tomentum.

Legs (anterior, intermediate as well as posterior ones) including tarsi, covered with fine and dense whitish tomentum, which absent at knees and on tibiae. All femora and tibiae also equipped with individual dark, long and erect setae. Colour dark, more or less metallic.

Genitals: Parameres rather coarse, quite variable in shape. Equipped with few setae on apices. Aedeagus variable similarly as parameres, moderately narrowed backwards and with blunt apex (Fig. 38).

Variability: Agapanthia (Smaragdula) grosseri is a species relatively variable in colour. But basic colour is metallic blue-green, sometimes blue or green. Anterior half of body mostly considerably darker, sometimes even black and without distinct lustre. Further variability is found in male genitals: differences in both parameres and aedeagi.

Differential diagnosis: Contrastingly to Agapanthia (Smaragdula) chylybaea, Agapanthia (Smaragdula) grosseri sp. nov. does not have white tomentum stripes on sides of the pronotum, the pronotum is also longitudinal in contrast to transversal pronotum of $A$. (S.) chalybaea. In $A$. (S.) grosseri sp. nov., the white pubescence of elytra is also distinctively absent compared to $A$. (S.) chalybaea, whose elytra are 
covered with considerable whitish hairs. A. (S.) grosseri sp. nov. can also be differentiated based on the absence of whitish pubescence on elytra from a further similar species Agapanthia (Smaragdula) persicola in which the whitish pubescence is distinct in posterior third of elytra. A further differentiating character is the pronotum punctation, which is definitely uniform in $A$. (S.) persicola without forming wrinkles. A. (S.) grosseri sp. nov. can also be differentiated from the two above mentioned species by its shorter and stronger parameres even in spite of the general variability in male genitals within the whole subgenus Smaragdula (Agapanthiini).

Distribution and biology: The new species is known from Turkey, Erzurum province, Ispir surroundings (Fig. 84, Type locality). The host plant is unknown.

Etymology: The taxon was named after its collector, Walter Grosser.

Agapanthia (Smaragdula) incerta Plavilstshikov, 1930

(Figs.: 1, 18, 40, 62, 89)

incerta Plavilstshikov, 1930: 12 , Type locality: Buchara mer., Garm, 15.6.

Geographic distribution: KI, TD, UZ.

Material examined: 1 ex. - Turkmenia, Kara-Kala, Gerkez, 18.5.1993 (PK); 1 ex. - Kyrgyzstan, Talas Mt., Manas MTS., 21.5.1999 (KH); 2 ex. - Uzbekistan, Samarkand, Aman-Kutan, 8.5.1987 (PJ).

Body length 7-12 mm, colour mostly green or blue-green. Pronotum with uniformly distributed punctation not forming wrinkles, rather sparser before apical edge. Antennae black or less frequently brown from antennomere 3, with weak greyish white pubescence not forming rings. Scutellum with pale pubescence. Elytra parallel, rounded on apex, with coarse punctation forming on surface area weak transversal wrinkles, with black pubescence, in apical part also with white pubescence, erect long setae present throughout elytra length.

Remarks: It is very similar to the species $A$. (S.) talassica, from which can be differentiated based on ratio of inferior eye lobe and tempora: in $A$. (S.) incerta, tempora as wide as length of inferior eye lobe (Fig. 7); in $A$. (S.) talassica, tempora are wider (about 1.2-1.4 x) than length of inferior eye lobe (Fig. 8), (Danilevsky, personal communication) .

Bionomics: Imagines occur on Astragalus sewertzowii, Meliloltus sp. and on Prangos sp.

Agapanthia (Smaragdula) intermedia Ganglbauer, 1883

(Figs.: 19, 41, 63, 90)

intermedia Ganglbauer, 1883: 543, Type locality: Central and South Europe.

Geographic distribution: AU, CT, CZ, FR, GE, GR, HU, IT, LU, MD, NL, NT, PL, SK, SP, ST, SZ, UK, RO, GG, KZ.

Material examined: 1 ex. - Czechia, Lipný, 1974 (LK); 2 ex. - Czechia, Stebno, 3.5.2007 (KH); 5 ex. Czechia, Stan, ex larva, 12.2013 (KH); 1 ex. - Czechia, Břeclav - Pohansko, 18.5.2000 (KH); 1 ex. - Czechia, Černolice, 28.5.1983 (KH); 1 ex. - Czechia, Moravia S, Lužice env., 28.5.2012 (KH); 1 ex. - Czechia, Bohemia or., Janovice env., 25.5.2003 (PJ); 2 ex. - Czechia, Moravia, Uherský Brod, 27.5.2018 (TL). 
Body length 7-13 mm, colour variable, metallic, with prevalence of blueish green tints. Pronotum with dense, uniform punctation, sometime with indicated stripes of white pubescence. Antennae usually with narrow circles of greyish white pubescence. Scutellum usually with dense, white pubescence. Elytra parallel, narrowed or rounded before apex, apex with dense punctuation not forming wrinkles. Elytra densely pubescent, only in basal third with sparse, erect setae. The typical character of the taxa dense, decumbent, white pubescence of elytra, particularly in their apical half.

Bionomics: The species is probably developed only in Knautia sp. (Dipsacaceae).

Agapanthia (Smaragdula) izzilloi Rapuzzi, Sama \& Kotán, 2013

(Figs.: 20, 42, 64, 91)

izzilloi Rapuzzi, Sama \& Kotán, 2013: 582, Type locality: Greece, Arkadia, S of Scortsinos, 450 m, 2.V.2012.

Geographic distribution: GR.

Material examined: 1 ex. PT - Greece, Ahaia, Trapeza, 2.V.2012 (PR).

A smaller species - 7-13 mm, still known only from the Peloponnese (GR), basic colour goldenish green, seldom blue, blueish green to bronze green, some specimens bicolour. Dense short white hairs on apical edge of elytra. Antennae from antennomere 5 black, long, extending beyond apex of elytra by 6 articles. Scutellar punctures along suture forming wrinkles. Pronotum longer than broader, with denser punctation on disc in middle, covered with long black hairs. Pronotum longer than wide, with dense punctation, which rather finer on the disc. Basal half of antennae usually with considerable rings of pale pubescence. Scutellum with dense white pubescence. Elytra parallel, with rounded apex, with dense and deep punctuation forming wrinkles along suture, covered with semierect sparse pubescence which stepwise reduced in length from base to half elytra length.

Remarks: The examined type specimen of $A$. (S.) izzilloi is relatively well distinguishable from the similar taxon, $A$. (S.) violacea by the lightly ringed antennae, sparser punctation of the pronotum, very sparse punctation of the mesoepisternum, antennae in males exceeding the elytra by six articles. I examined additional material from the type locality A. (S.) izzilloi and vicinity. For this material I was not able to determine unequivocally whether it was $A$. (S.) izzilloi or $A$. (S.) violacea. The above-mentioned complex of characters was never uniform, only a few specimens had sparse punctation of the mesoepisternum, and the light ringing of the antennae was almost always absent. In contrast, the same characters - ringed antennae and sparser punctation of the pronotum - can be found in many specimens of $A$. (S.) violacea from central Europe. However, I found the sparse punctation of the mesoepisternum in specimens only from the Peloponnese. The parameres show a difference in curvature, the curvature of the examined specimen of $A$. (S.) izzilloi being bigger than that of the specimens of $A$. (S.) violacea in which parameres are rather straight. The shape of the aedeagus is the same as in some specimens of $A$. (S.) violacea from central Europe. In males $A$. (S.) violacea the antennae extend beyond the elytra by five articles.

Bionomics: Imagines were found on Psoralea bituminosa (Fabaceae). 
Agapanthia (Smaragdula) kadleci sp. nov.

(Figs.: 21, 43, 65, 92, 93)

Type material: Holotype ô - Turkey, Anatolia or., Buglan Gecidi 1640 m, Murat Daglari, 13.06.1991 (NMP);

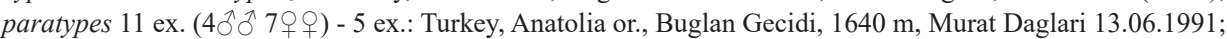
4 ex.: Turkey, Anatolia or., Buglan Gecidi , Mus, 1600 m, 14.06.1992; 1 ex.: Turkey, Anatolia or., Karakurt env. (Arax riv.), 09.06.1992; 1 ex.: Turkey, vill. Mus, Mus Ovasi, 1520 m, 18.06.1986 (NMP, KH).

Description: Body length 8.1-12.2 mm in males, 9.2-12.9 in females, bright blueish green to green with metallic lustre throughout, anterior part of body (head, thorax and anterior one third of elytra) additionally with slight blue to moderate blueish violet tint.

Head with dense punctation, which most distinct on frons and vertex, and with long, erect, black setae, which densest and longest on frons. Anterior and posterior sides of genae with considerable white stripe merging in bordering of eye inferior half. In frontal view, genae distinctly throttled on sides (Fig. 64). Head, including outer edge of mandibles, labrum and less frequently also body underside with dense, yellowish white pubescence. All white pubescence reduced considerably. Palpi continuously pointed, black, sometimes with fine metallic tint, distinctly paler only on apex. Antennae long, exceeding body length by 4-5 antennomeres in males and by 3 antennomeres in females. Scapus finely but distinctly wrinkled-punctate, antennomeres 1 and 2 distinctly metallic, remaining antennomeres black, only antennomeres 3 and 4 usually with very weak metallic effect. All antennomeres with very fine, more or less distinct, whitish tomentum, antennomeres 3-6 having inner side with long, erect setae, remaining antennomeres only with one or two setae. Scapus distinctly throttled before end, as long as about three quarters of antennomere 3 length.

Pronotum transversal, moderately widening backwards, throttled at anterior as well as posterior margins (more distinctly anteriorly). Pronotal punctation dense, indicating fine wrinkles in anterior half of pronotum and at basal pronotal margin (Fig. 21). Prothorax anteriorly with more or less dense white hairs. Scutellum rectangular, smooth and shining, with metallic effect, exceptionally with whitish hairs.

Elytra parallel in first third, slightly sinuate behind humeri, with dense uniform punctation suggesting presence of fine transversal wrinkling on elytral disc area. Elytra only with sparse, long, erect setae, which longest on disc, in first third. Suture very distinct throughout, except for first quarter behind scutellum, where it is confluent with elytral surface. Elytral width at humeri equals to 2.3-2.5 times total elytra length. Ventral side as green, metallic, shining as dorsal side, with white hairs being densest on metepisternum. White pubescence also reduced considerably.

Legs metallic, similarly as remaining body, covered with white, sometimes rather yellowish pubescence, which densest and most distinct in terminal halves of tibiae and partially also on inner sides of femora; tibiae and femora sometimes with individual long, erect, black setae.

Genitals: Parameres rather narrow, parallel, sometimes moderately bent inwards. Aedeagus parallel, with blunt and moderately sinuate apex at end (Fig. 42).

Variability: The examined specimens form a compact group, which is only variable as to fine differences in the basic, green, metallic colour and larger or smaller reduction in the white pubescence on the head, body underside and legs.

Differential diagnosis: Agapanthia (Smaragdula) kadleci sp. nov. can be differentiated from a similar species Agapanthia (Smaragdula) lais based on the pronotum punctate sculpture: in $A$. (S.) kadleci sp. nov. the punctation forms distinct thin wrinkles, whereas 
in $(S$.) lais the punctation is loosened. A further distinct differentiating character is the ratio of eye length to gena length in frontal view: in $A$. (S.) kadleci sp. nov., eye as long as or moderately shorter than gena, whereas in A. (S) lais, gena is about 1.5 longer than eye. A further character is the episternum shape, which is on lower side of first third more sinuate in $A$. (S.) kadleci sp. nov. compared to $A$. (S) lais. A further species resembling $A$. (S.) kadleci sp. nov. is Agapanthia (Smaragdula) naciaye, from which it can be differentiated by the absence of white rings of antennomeres and more subtle body shape in general. $A$. (S.) naciaye has distinctly shorter elytra, more robust antennae and legs, antennae also being shorter compared to $A$. (S.) kadleci sp. nov.. A. (S.) naciaye has also more uniformly and more sparsely punctate pronotum, the punctation not forming wrinkles as distinct as in $A$. (S.) kadleci sp. nov..

Distribution and biology: The new species is known only from Turkey. The host plant is unknown.

Etymology: The taxon is named after its collector, MUDr. Stanislav Kadlec $(\dagger 2008)$, who deposited all the type specimens and his collection in the National Museum Praha.

\section{Agapanthia (Smaragdula) lais Reiche \& Saulcy, 1858}

(Figs.: 4, 22, 44, 66, 94)

lais Reiche \& Saulcy, 1858: 21, Type locality: Du Péloponése [an incorrect locality].

\section{Geographic distribution: IS, JO, LE, SY, TR.}

Material examined: 7 ex. - Turkey, Adana p., $5 \mathrm{~km}$ E of Hasanbeyli, 22.5.2011 (LS); 3 ex. - Israel, Hare Gilboa', Merav Har Avinadav, 420 m, 11.IV.2011 (TAU); 1 ex. - Israel, Har Karmila (TAU); 1 ex. - Israel, Har Tayyasim, 740 m, 27.III.2011 (TAU); 1 ex. - Israel, Har Dov, 17.III.1995 (TAU); 1 ex. - Israel, Qazzin, 2.V.1998(TAU); 1 ex. - Israel, Nahal Barkan, 7.V.1997(TAU); 1 ex. - Israel, En Zeitim, 13.V.1998 (TAU); 1 ex. - Israel, Nkziv, 1.V.1999 (TAU); 1 ex. - Israel, Nahal Qazrin, 9.V.2006 (TAU); 1 ex. - Israel, Shemurat Pura, 27.III.2000 (TAU); 1 ex. - Israel, 'En Zetim, 8.V.2013 (TAU); 1 ex. - Israel, Shoham, 15.III.2013 (TAU); 1 ex. - Israel, 'Emeq HaEla, 27.III.2013(TAU); 1 ex. - Israel, Tel Aviv Dunes, 12.III.2002 (TAU); 1 ex. Israel, 'Emeq HaEla, 20.IV.2005 (TAU); 1 ex. - Israel, Natah Orev, 6.V.2000 (TAU); 1 ex. - Israel, Lehavim Junction, 7.IV.1998 (TAU); 1 ex. - Israel, Shoham, 17.III.2006 (TAU); 1 ex. - Israel, Ha Yarden, moat of castle, 26.III.2001 (TAU); 2 ex. - Israel, Kokhav, ha Yarden, 26.III.2001 (TAU); 2 ex. - Israel, Qedumin. 2.IV.1999 (TAU); 1 ex. - Israel, Qedumin Park Znirim, 370 m, 22.III.2016 (TAU); 2 ex. - Israel, HaKefar HaYarog, Zomet Gelilot, 22.IV.2011 (TAU); 1 ex. - Israel, Mahseya S., Deir Aban ruins, 265-300 9.III.2016(TAU); 1 ex. - Israel, Ma'agar Bental, 11.V.2016 (TAU); 1 ex. - Israel, Qedumin, Park Znirim, 370 m, 22.III.2016 (TAU); 1 ex. - Israel, Nahshom, 21.III.1998 (TAU); 1 ex. - Israel, Qedumin cemetry, 370 m, 30.XII.2014 (TAU); 1 ex. - Israel, Nahal, Oren, 27.III.2000 (TAU); 1 ex. - Israel, Umm EiGhanam, 9.IV.2012 (TAU); 1 ex. - Israel, Zomet Rantis, 28.II.2001 (TAU); 1 ex. - Israel, Ramot - Naftaly, 15.III.1998 (TAU); 1ex. - Israel, 'Emeq HaEla, 10.IV.2006 (TAU); 1 ex. - Israel, Zomet Lehavim, 263 m, 22.III.2006 (TAU); 1 ex. - Israel, Zomet Pelugot, 93 m, 24.III.2006 (TAU); 1 ex. - Israel, Hare Gilboa', Har Avinadav, 15.IV.2012 (TAU); 2 ex. - Israel, Kokhav Ya 'Ir, Ya'ar Sapir, 160 m, 16.II.2010 (TAU); 1 ex. - Israel, Nahal Qazrin, 9.V.2006 (TAU); 1 ex. - Ilanot, S Hadera, 22.III.1994 (TAU); 2 ex. - Israel, Matta, 9.XI.2006 (TAU); 9 ex. - Syria, Mashtal Helu E of Safita, 30.IV.2008 (VS); 12 ex. - Syria, Crac de Chevaliers, 18.IV.2008 (PŠ).

Body length 11-16 mm, colour usually yellow green, green or blueish green. Pronotum with very dense punctuation, which very moderately loosened at the middle, with small bright, glabrous area, frequently with small bump in apical part, before edge. On pronotum sides frequently with few hairs forming more or less distinct narrow row from apical edge forward. Antennae usually with fine, pale pubescence not forming rings or 
only with small rings at antennomere bases. Scutellum with punctuation and white pubescence, sometimes almost entirely smooth and bright, with individual thin hairs on sides. Elytra more or less converging towards apex, but sometimes almost parallel, with punctuation sometimes forming weak wrinkles, but sometimes forming indications of two longitudinal ribs on each side. Elytra with moderate, short, erect pubescence, pubescence longer and more erect in basal third, with pale hairs in apical half.

Remarks: Some individuals have scutellum entirely glabrous and smooth, only with few small punctures and few thin hairs. These individuals can be confused with $A$. (S.) petranyi, but it can be safely differentiated based on lengths of tarsomeres: in dorsal view, $A$. (S.) lais has tarsomere 4 as long as or shorter than tarsomeres 2 and 3 combined (Fig 4). A. (S.) petranyi has tarsomere 4 longer than tarsomeres 2 and 3 combined in dorsal view (Fig 3).

Bionomics: Imagines occur on Onopordum macrocephalum (Asteraceae) and Silybum marianum (Asteraceae).

Agapanthia (Smaragdula) naciyae Rapuzzi \& Sama, 2012

(Figs.: 23, 45, 67, 95, 96 )

naciyae Rapuzzi \& Sama, 2012: 676, Type locality: Turkey, Erzincan prov., 12 Km W Refahiye, 1589 m., 9.V.2011, ex larva Astragalus sp., emerged 1.VI.2011.

Geographic distribution: TR.

Material examined: 1 ex. - Turkey, Erzincam, 12 km West Refahyie, 9.5.2011 (KH); 1 ex. - Turkey, Erzincan prov., Refahyie/Tokat cross, 13 km N Rafahyie, 13.VI.2012 (TT); 1 ex. PT - Turkey, Erzincan prov., Refahyie/ Tokat cross, 13 km N Rafahyie, 9.VI.2012 (KH).

Body length 8-11 mm, rather pale yellowish green, sometimes greenish blue. Head and pronotum with dense, erect, long, black setae. Pronotum with dense punctation, forming fine wrinkles at apical and basal edges. Pale, greyish brown, antennal pubescence not forming rings. Elytra parallel, with rounded apex, with dense punctation, which distinctly wrinkled at humeri, wrinkles becoming less distinct towards apex, entirely covered with long, erect setae and in apical part additionally with decumbent, brownish pubescence. Pronotum as well as elytra without pale pubescence.

Remarks: The conspicuously, entirely shining and smooth scutellum is a feature typical of the taxon and can be used for the differentiation from other taxa of the group. The bright, light green or light blueish green colour is a further character.

Bionomics: The species develops in Astragalus sp. (Fabaceae).

\author{
Agapanthia (Smaragdula) osmanlis Reiche \& Saulcy, 1858 \\ (Figs.: 24, 46, 68, 97, 98) \\ osmanlis Reiche \& Saulcy, 1858: 19, Type locality: De Costantinople [Istanbul, Turkey]
}

Geographic distribution: BU, GR, HU, ME, RO, SB, SK, RO, TR.

Material examined: 2 ex. - Turkey, Kacakar-Yusufeli, 17.VI.2005 (KH); 1 ex. - Bulgaria, Jasna Polana u Primorie, 23.VI.2003 (KH); 1 ex. - Bulgaria, Jasná Polanka u Primor, 23.VI.2008 (LK); 1 ex. - Turkey, 
Kacakar-Yusufeli, 17.VI.2005 (KH); 3 ex. - Turkey, Erzurum prov, 85 km S Ispir, 1900 m, 23.VI.2014 (WG); 4 ex. - Bulgaria, Fassanovo, env. Lozenec, 28.VI.2004 (WG); 2 ex. - Bulgaria, Izgrev env, 26.VI.2004 (WG); 7 ex. - Bulgaria, Primorsko env., 27.VI.2004 (WG); 1 ex. - Bulgaria, Klokotnica, 25.VI.2010 (WG); 1 ex. Turkey, Samanta, 21.IV.1992 (WG); 19 - Bulgaria, Primorsko env., 25.-27.VI.2004 (PJ); 9 ex. - Turkey, Erzurum Kop Gecidi, 2200 m.n.m., 20.7.2008 (DN).

Body length 10-16 mm. Typical colours green, blue or blueish green. Antennae with greyish white pubescence, usually forming pale rings in basal half of antennomeres. Pronotum with not very coarse punctation, on each side and along midline with stripes of white hairlike setae. These stripes variously reduced or quite missing. Scutellum usually with dense, white pubescence. Elytra parallel, moderately narrowed before apex, apex rounded, with rather long, erect setae in basal third, remaining pubescence mostly fine and decumbent, black and white, white pubescence being denser than black ones. Elytral punctation sometimes forming two indicated longitudinal ribs on each side. Dense, white or greyish white elytral pubescence typical of taxon, which rarely reduced.

Remarks: Populations from different locations can differ in the elytral punctation and pubescence.

Bionomics: Imagines are found on Cephalaria procera (Dipsacaceae).

Agapanthia (Smaragdula) ozdikmeni Rapuzzi \& Sama, 2012

(Figs.: 25, 47, 69, 99, 100)

ozdikmeni Rapuzzi \& Sama, 2012: 673, Type locality: Turkey, Tunceli prov., 46 km N Tunceli, 1086 m., 11-18.V.2011, ex larva Cephalaria sp., emerged 28-30.V.2011.

\section{Geographic distribution: TR.}

Material examined: 1 ex. PT - Turkey, Pulumur, 2-7 km NW Pulumur, 26.-27.VI.2009 (KH); 1 ex. PT Turkey, Pulumur, 2-7 km NW Pulumur, 26.-27.VI.2009 (ZK); 2 ex. - Turkey, Pulumur, 2 km N of Tunceli, 18.6.2014 (KH); 2 ex. - E Turkey, (2 km N of) Yukan Ulupinar $30 \mathrm{~km}$ SE Darende, 38²5N 37³3E, 27.5.2001 (NMP).

Body length 12-15 mm. Whole body conspicuously clear blue, with minimum colour variability, only rarely greenish (particularly on pronotum). Pronotum with dense punctation forming few narrow transversal wrinkles at apical margin. Antennae with white pubescence from antennomere 3, apical third of antennomeres usually dark. Scutellum usually with dense, pale pubescence in apical part. Elytra narrowing towards apex, apex round, punctation producing wrinkles distinct already from base. Pale pubescence of elytra present only in apical half, short, black pubescence present throughout, at base sparser and higher with few sparser and longer setae. Elytral punctation sometimes slightly indicating longitudinal ribs. Pale pubescence of antennae forming rings already from antennomere 3.

Remarks: RAPUZZI \& SAma (2012) mentioned the species as probably endemic to a valley between Pülümür and Tunceli in the Tunceli prov. (TR). But in the S. Kadlec collection (NMP), there are two specimens from Darende, Malatya prov.. From the very similarly coloured taxon $A$. (S.) posti, it can be particularly differentiated based on whitish pubescence in the apical third of elytra, which is quite missing in A. (S.) posti. In contrast to this, a population of $A$. (S.) osmanlis from Bulgaria (for example from the 
Primorsk area) is almost identical with specimens of $A$. (S.) ozdikmeni. In specimens compared, there is identical colour, pronotal and elytral punctation, length of tarsomeres, some specimens also having identical areas of the elytral pubescence. The difference is only in the elytral pubescence, which is finer and sparser than that of $A$. (S.) ozdikmeni, but certain specimens of $A$. (S.) osmanlis are also very similar in this character.

Bionomics: The whole type material comes from stalks of Cephalaria procera (Dipsacaceae).

Agapanthia (Smaragdula) persicola Reitter, 1894

(Figs.: 9, 26, 48, 70, 101, 102, 103)

persicola Reitter, 1894d: 146, Type locality: Astrabad, Araxesthal (Iran, Gorgan).

Agapanthia violaceipennis Pic, 1904: 9.

Geographic distribution: AB, AR, GG, IN, TM, TR.

Material examined: 3 ex. - Turkey, Kesecik 19 km S Ilgaz, 30.05 .1994 (PK); 3 ex. Iran, Khorásán, Minudasht 64 km NE, 19.-20.V.2003 (PK); 2 ex. - Armenia, Sevan Lake, Sogar, 26.5.1985 (PK); 1 ex. - Iran, Mazandaran, Kalardasht, 5.5.2006 (PK); 1 ex. - Gruzia, Dzhvari, 28.5.-5.6.1985 (PK); 2 ex. - Armenia. Tashtun, 19.22.6.2012 (TP); 1 ex. - Armenia, Aragats, Alpine Park, 11.6.2012 (TP); 1 ex. - Armenia, Arailer, Saghmosavan env., 9.6.2012 (TP); 2 ex. - Armenia, Geghard Monastery road, 10,6.201 (TP); 2 ex. - Turkey, Elazig p., 4,5 km Ne of Elazig, 23.5.2011 (LS); 1 ex. - Armenia, Teghut 2,5 km SSE, 1500 m, 3.-4.6.2016 (JK); 9 ex. Armenia, S Mts.Zangezur, Lichk 2 km, 01.06.2016 (JK); 3 ex. - Armenia, Geghard Monastery,Road, 2.-3.6. (JK); 1 ex. - Armenia, Gndevaz 6 km SW, 28.05.2016 (JK); 1 ex. - Iran, prov. Azerbajan, 11 km SE Serov, 30.-31.V.2017 (DN); 2 ex. - Iran, Mazandaran prov., 2 km E Keris,20.05.2017(DN); 2 ex. - Iran, Kordestan prov., 36 km S Saqqez, 27.05.2017 (DN); 6 ex. - Iran, Gílán prov., 12 km W Rostamabad, 1550m, 6.VI.2017 (KH); 6 ex. - Iran, Golestan prov., 4 km N of Dasht, Golestan Valley 900m, 17.V.2017 (KH); 1 ex. - Iran, Gílán prov., 6 km of Majara, 2200 m, 3.VI.2017 (KH); 1 ex. - Iran, W. Azerbajan, 14 km S Kaleybar, 1430 m, 1.VI.2017 (KH); 1 ex. - Iran, Mazandaran prov., Alamdar Mahaleh, 5m, 17.V.2017 (KH); 2 ex. - Georgia, E of Dedoplitskaro, Vashlovani NP 700m, 1.-2.V.2017 (VS); 2 ex. - Iran, 2 km E Kenis, 20.05.2017 (LH); 1 ex. - Georgia, E of Dedoplitskaro, Vashlovani NP 700m, 1.-2.V.2017 (VS); 1 ex. - Armenia, Shurnhuk3 km N, 9.VI.2014 (JK); 2 ex. - Iran, Dasht - i - Naz, 12.V.1972 (TAU); 13 ex. - Georgia, Dedoplistskalo env. JV, 19.-21.5.2018 (JCH); 5 ex. - Georgia, Gori env. Sever, 22.-25.5.2018 (JCH); 1 ex. - Georgia, Saguramo, 22.5.2018 (JCH); 1 ex. - Georgia, Zekari, 25.5.2018 (JCH); 3 ex. - Armenia, Teghut 2,5 km SSE - Lake Parz, 28.5./3.6.2015 (JCH); 17 ex. - Iran, Golestan prov., 6 km SW Razi 1970 m 19.5.2018 (KH); 8 ex. - Iran, Gílán prov., 8 km W Rostamabad, 1150 m, 2.-25.5.2018 (KH);3 ex. - Iran, Gilan prov., Rostamabad env., $1650 \mathrm{~m}$, 1.-2.6.2019 (KH); 1 ex. - Armenia, Geghardt Monastery Road, SE Goght, 10.6.2012 (PJ); 4 ex. -SV Armenia, N. Tasthun,19.-22.6.2012 (PJ); 13 ex. - Georgia, NP Vashlovani, 11.-15.5.2016 (PJ); 1 ex. - Turkey, Samanta, 21.4.1992 (PJ); 3 ex. - Armenia, Geghard Monastery env., 27.5.2013 (TL); 1 ex. - Armenia, Yerevan env., 26.5.2013 (TL); 4 ex. - Armenia, Martuni, 28.5.2013 (TL); 7 ex. - Armenia, Lichk env., 1.6.2013 (TL); 5 ex. - Iran, Mazandaran pr., 1 km NW of Kinj, 20.5.2017 (TL); 5 ex. - Armenia, Khosrov Forest,23.-24.5.1990 (MD); 3 ex. - Armenia, Megri, 10.5 .1983 (MD); 3 ex. - Armenia, Shvanidzor, $1420 \mathrm{~m}, 38^{\circ} 59^{\prime} 14^{\prime \prime} \mathrm{N} 46^{\circ}$ 22'07“'E, 9.5.2005 (MD); 1 ex. - Armenia, Idzhevan Kiranz, 30.4.-2.5.1989 (MD).

Body length 7-15 mm, colour mostly metallic greenish blue, sometimes only green, blue or elytra blue and pronotum green, or anterior part black, remaining body blue or violet. Colour variability similar to $A$. (S.) violacea. Head with dense, fine and regular punctation. Pronotum with typical very dense, regular and fine punctuation not forming wrinkles. Pronotum transversal in larger specimens (in these cases, punctation sometimes coarser with indicated wrinkles), in smaller specimens usually longitudinal, more or less convex laterally, widening usually shifted backward from middle. Antennae long, in males exceeding body by almost one third body length, only in females moderately 
shorter, antennomeres 1 and 2 being distinctly metallic. Antennae with rather long, erect setae on inner side, sometimes entirely with whitish pubescence or this pale pubescence forms only weak circles at bases of antennomeres. Scutellum transversal, with very fine punctuation and usually with pale pubescence. Elytra 2.5 times longer than wide at humeri, entirely with coarse punctation forming weak transversal wrinkles at suture. Head, prothorax and basal half of elytra with erect, rather long, black setae, apical half of elytra with decumbent black and pale pubescence, without erect setae. Head sometimes with dense, white pubescence.

Remarks: The uniform punctation of the pronotum and white pubescence in the posterior elytral third are typical of the taxa. According to these characters, $A$. (S.) persicola is easy to differentiated from a similar taxon, $A$. (S.) violacea. From southern Georgia, I know individuals with reduced white elytral pubescence, which is very sparse or even missing. These specimens were collected at their location together with usually pubescent ones. The pronotum of the most specimens from Georgia has a moderately coarser punctuation compared to specimens from Armenia or Iran.

Bionomics: Imagines are usually found on Carduum sp. (Asteraceae) or Sonchus sp. (Asteraceae). In the eastern part of the mountain range Elborz (Iran), I caught rather numerous imagines on Urtica sp. These imagines have a moderately wider head, similarly as $A$. (S) violacea.

\section{Agapanthia (Smaragdula) pesarinii Sama \& Rapuzzi 2010}

(Figs.: 6, 12, 27, 49, 71, 104, 105)

pesarinii Sama \& Rapuzzi, 2010: 177, Type locality: Turquie mér., Icel: Çamalan, 5.VI.1981.

\section{Geographic distribution: TR, SY.}

Material examined: 2 ex. - Turkey, Elazig p., 4,5 km NE of Elazig, 23.5.2011 (LS); 3 ex. PT - Turkey, Toros mts., Sarikavak, 18.V.2005 (WG); 8 ex. - Turkey, near Amas, 810 m, 26.V.2010 (WG); 1 ex. - Turkey, Hasanbeyli env., Nurdagi gecidi 1050-1350m, 17.05.2011 (MČ); 1 ex. - Turkey, TR mer., Pozanti, 20-29. VI.1992 (TP); 1 ex. PT - Turkey, Camliyayla, 20.5.1997 (KH); 7 ex. - Turkey - S, (Içel), Karahidirli vill., h= 870-940 m, 7.6.2011 (MD).

Smaller species (8-12 mm), similar to A. (S.) amitina. Larger specimens usually with distinctly elongate body. Colour mostly blue, sometimes greenish blue to green. Pronotal and elytral punctation not forming wrinkles. Scutellum bearing white pubescence. Pronotum longer than wide. Antennae bearing weak, pale pubescence not forming rings. Elytra parallel, elongate, rounded on the apex, without white pubescence, covered with semierect setae, which stepwise shortened backwards from base. Apical part of elytra with white pubescence. Tarsi conspicuously extended, third tarsomere usually shorter than second one, larger specimens of $A$. (S.) pesarini slimmer body, distinctly relatively longer compared to other taxa of group, body length of smaller species often normal.

Remarks: SAMA \& RAPUZZI (2010) also mentioned a population from southern Turkey, which could be considered after a future study as a subspecies of the taxon with respect to a difference in the ventral pubescence. Larger material should be studied to provide more accurate diagnosis.

Bionomics: Imagines of $A$. (S.) pesarini were found on Psoralea bituminosa - all of them the family Fabaceae. 
Agapanthia (Smaragdula) petranyi Kotán, 2014

(Figs.: 3, 28, 50, 72, 106, 107)

petranyi Kotán, 2014: 64, Type locality: Iran, Kordestan Province, 3505’04.13”N, 4652'58.56” E, 1350 m, 18-19.IV.2010.

Geographic distribution: IN.

Material examined: 8 ex. - Iran, Kordestan prov. Soarian env., 28.4. 2019 (type locality) (TT).

Body length 10-16 mm, colour very variable, most frequently pale yellowish green or greenish blue, sometimes with red tint, or pale yellowish with purple tint. Pronotum with strong punctation forming weak wrinkles in basal third and at apical margin. Antennae with greyish white hairlike setae forming no rings. Scutellum smooth, only with few fine punctures and few fine hairs laterally, bent at middle, with finely pierced posterior margin at middle. Elytra moderately converging towards apex in males, more distinctly converging in females. Elytra with strong punctation, forming only individual punctures at base around scutellum, and fine wrinkles on remaining area of elytra. Elytra with dark, erect setae throughout, which longest in basal third and moderately stepwise reduced in length towards apex. In apical third, elytra with fine, white pubescence.

Remarks: This taxon is relatively variable in colours.

Bionomics: Imagines on Astragalus sp. (Fabaceae)

Agapanthia (Smaragdula) postii Hodek \& Tichý, 2021

(Figs.: 29, 51, 73, 108, 109)

postii Hodek \& Tichý, 2021: Type locality: TR, Tunceli, Munzur Valley, 23-30 km of Tunceli, 1000-1700 m, 21.-22.V.2013.

Geographic distribution: TR.

Material examined: 1 ex. HT - Turkey, Tunceli, Munzur Valley, 23-30 km of Tunceli, 1000-1700 m, 21.-22. V. 2013 (TT); 3 ex. PT - Turkey, Tunceli, Munzur Valley, 15-20 km of Tunceli, 1000-1100 m, 18. V. $2012 ; 11$ ex. - Turkey, Tunceli, Munzur Valley, 23-30 km of Tunceli, 1000-1700 m, 21.-22. V. 2013; 3 ex. - Turkey, Tunceli, Munzur, 23 km of Tunceli, 1050-1060 m, 6. V. 2014, (KH, PR, TT).

Body length 9-13 mm, colour typically considerably dark brown, sometimes with violet or greenish tint. Pronotum with fine, dense and regular punctation without wrinkles, punctures moderately denser in apical half. Antennae with sparse, whitish hairs on inner side and just only at base, scapus granulate-wrinkled. Scutellum with sparse, white pubescence. Elytra parallel, with rounded apex, punctation simple in basal half, moderately wrinkled only at base, in apical half finer and finely, transversally wrinkled. Apical half of elytra with sparse, longer, erect, dark setae, in basal half with shorter and decumbent pubescence together with dense, white pubescence.

Remarks: Remarkably deep blue, similarly as $A$. (S.) ozdikmeni coming from about the same area. A. (S.) postii has elytra more parallel, without white pubescence. The species $A$. (S.) friwaldszkyi is also similar, but its elytra bears only erect, sparse setae, without the presence of decumbent pubescence and its colour is rather green. This species can be differentiated from $A$. (S.) persicola by a different punctation of the pronotum. 
Bionomics: All the species included in the type series were collected on Valeriana sp. (Valerianaceae).

\section{Agapanthia (Smaragdula) psoraleae Sama \& Rapuzzi, 2010}

(Figs.: 5, 30, 52, 74, 110)

psoraleae Sama \& Rapuzzi, 2010: 176, Type locality: Liban, Jbail: Qartaba, 1000-1300 $\mathrm{m}, 15 . \mathrm{V} .2000$.

\section{Geographic distribution: LE, IS.}

Material examined: 3 ex. PT - Lebanon, Jbail 1400 m, Qartaba, Mazraat el Syad, 10.V.2000 (WG); 1 ex. PT - Lebanon, Qvartaba, 1400 m, Mazraat el Syad, 11.05.2000 (OK); 2 ex. - Iran, Dasht-i-Naz, 12.V.1972 (TAU); 2 ex. - Israel, Qame Shomeron, 18.III.2016 (TAU); 1 ex. - Israel,Park ha Yarden, 210 m, 4. IV. 2011 (TAU); 1 ex. PT - Lebanon, Jbail 1400 m, Qartaba, Mazraat el Syad, 10.V.2000 (KH).

Body length 7-12 mm, malachite blue, green or bicolour, without any microsculpture and thus shining. Scutellum mostly with white pubescence not forming rings on antenna. Scapus mostly distinctly throttled before its end (Fig. 5). Pronotum longer than wide, with dense punctation forming weak wrinkles. Elytra parallel, with rounded apex, and dense punctation in apical half, covered with sparse, semierect pubescence, which longer and more distinct in basal half. Elytral apex covered with white pubescence.

Remarks: A new record for Israel.

Bionomics: All type specimens were collected on Psoralea bituminosa (Fabaceae).

Agapanthia (Smaragdula) rapuzzii Hodek \& Tichý, 2021

(Figs.:1, 31, 53, 75, 111, 112)

rapuzzii Hodek \& Tichý, 2021: Type locality: TR, Tunceli, Munzur Valley, 23 km of Tunceli, 1050-1060 m, 6. V. 2014.

\section{Geographic distribution: TR.}

Material examined: 1 ex. HT - Turkey, Tunceli, Munzur valley, 23 km of Tunceli, 1050-1060 m, 6. V. 2014 (TT); 5 ex. PT - Turkey, Tunceli, Munzur valley, 23 km of Tunceli, 1050-1060 m, 6. V. 2014; (1 q): Turkey, Tunceli, 15 km W of Ovacik, 5 km NW Ziyaret, 1400-1600 m, 6. V. 2014; (2 đ̊̊,, 3 o o ): Turkey, Muş, 35 km Muş-Kulp Yolu, Yörecik, 1400-1900 m, 11. V. 2014, (TT, PR, KH).

Body length 6.9-12 mm, body rather flat, green or greenish blue. Pronotum rather transversal, with dense punctation forming wrinkles particularly in basal half. Antennae short, exceeding body by length of one antennomere, with very fine, whitish pubescence not forming rings. Scutellum with sparse, fine punctures and sparse, fine, pale pubescence. Elytra short, parallel, or moderately convex post-basally, vertex rounded, punctation rather finer compared to other taxa of group, in basal half moderately loosened, in apical half moderately denser, but less coarse and forming fine wrinkles. Elytra only with sparse, erect, dark setae, which longer in basal half and decrease in length towards apex.

Remarks: The species is easy to differentiate from other taxa of the subgenus Smaragdula based on its short and wide body. Antennae are also shorter compared to other taxa of the group. 
Bionomics: The type material was collected on Prangos sp. (Apiceae).

\section{Agapanthia (Smaragdula) talassica Kostin, 1973}

(Figs.: 8, 32, 54, 76, 113, 114 )

violacea talassica Kostin, 1973: 223, Type locality: Западный Тянь-Шань (Western Tian-Shan).

\section{Geographic distribution: KI, KZ.}

Material examined: 1 ex. - Kyrgyzstan, Kyz Kiya, Kyz Kuyo env., 19.V.-3.VI.2017 (KH); 1 ex. - Kyrgyzstan, Chandalash Mt., Chakmak-Suu riv., 31.05.2010 (WG); 1 ex. - Kyrgyzstan, Kyz Kia, Kyz Kuyo env., 19.5.2017 (KH); 2 ex. - Kazakhstan, 16 km N Kentau, Bayaldyr riv., 6.-8.5.2014 (KH).

Body length 7-11 mm, colour mostly, blue, green or blueish green. Pronotum with dense punctation not forming wrinkles, rather loosened before basal edge. Antennae with white, fine pubescence not forming rings. Antennomeres sometimes darkened only on apical end. Scutellum with white pubescence. Elytra parallel moderately converging backwards, with strong, moderately wrinkled punctation, with longer, erect, black setae, which only moderately reduced in length to apical end, in apical half also with white pubescence, long, erect, black setae present throughout elytra length.

Remarks: It is very similar to $A$. (S.) incerta, from which it can be differentiated based on ratio of inferior eye lobe and tempora: in $A$. (S.) incerta, tempora as wide as length of inferior eye lobe (Fig. 7); in $A$. (S.) talassica, tempora are wider (about 1.2-1.4 x) than length of inferior eye lobe (Fig. 8).

Bionomics: Imagines occur on Astragalus sieversiana.

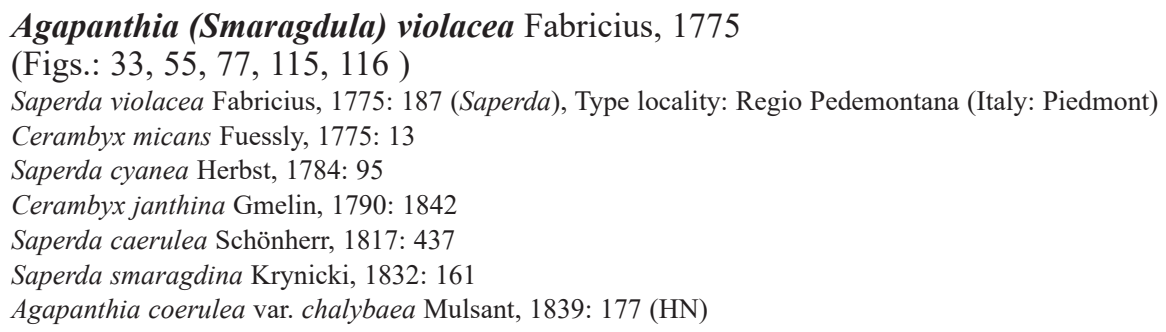

Geographic distribution: AL, AU, BE, BU, CT, CR, CZ, FR, GE, GR, HU, IT, LA, LU, MC, MD, NT, PL, PT, SK, SL, SP, ST, TR, UK, RO, AB, AR, ES, GG, KZ.

Material examined: 1 ex. - Slovakia, Štůrovo, V.1968 (VS); 1 ex. - Greece, Kastraki 3 km NE, 2-3.V.2017 (LK); 1 ex. - Bulgaria, Asenovgrad-Topolovo, 23.-25.V.1986 (VS); 1 ex. - Slovakia, Štůrovo, V.1968 (VS); 1 ex. - Romania, Crucea, 3.V.2015 (VS); 1 ex. - Bulgaria, Harmani,Lyubimets env. 59 m, 14.05.2011 (MČ); 1 ex. - Turkey, Sultan Dag, 14.7.1991 (PŠ); 21 ex. - Bulgaria, Pirin Mts., Rožen near Melnik, 4.7.2004 (WG); 3 ex. - Bulgaria, Primorsko env., 27.6.2004 (WG); 3 ex. - Bulgaria, Liubinec, 25.5.2010 (WG); 4 ex. Bulgaria. Lozenec env., 28.62004 (WG); 3 ex. - Greece, Preveza, 10.6.1992 (WG); 1 ex. - Serbia, 10 km E Pirot, 7.6.2012 (WG); 4 ex. - Bulgaria, Kiten, 24.-29.6.2004 (WG); 1 ex. - Greece, Peloponnesos, Arcadia, Paradisia, 4.6.2011 (WG); 2 ex. - Czechia, Kurdějov, 2.6.2009 (KH); 2 ex. - Czechia, Mikulov, Turold, 14.5.2011 (KH); 1 ex. - Czechia, Pouzdřany, 2.5.2009 (KH); 1 ex. - Czechia, Brno-Slatina, 2.5.1992 (KH); 1 ex. - Czechia, Pouzdřany, 28.6.1999 (KH); 3 ex. - Greece, Agii Theodoroii, 1.6.2010 (KH); 1 ex. Macedonia, 2 km N of Zavoj, 30.5.2010 (KH); 1 ex. - Greece, Trikala, Kastraki, 1.-4.6.2010 (KH); 12 ex. Romania, Ravensca, 7.-10.5.2010 (KH); 2 ex. - Greece, Karperovo env., 11.-12.6.2012 (KH); 1 ex. - Czechia, 
Brno-Kohoutovice, 5.6.1993 (KH); 3 ex. - Kazakhstan, Putinsevo env., 30.5.2016 (KH); 2 ex. - Kazakhstan, Samsonovka, 31.5.2019 (KH); 1 ex. - Kazakhstan, Kaznakovka, 1.6.2016 (KH); 1 ex. - Greece, Thesalia, Pindos Mts., Nereida, 4.-8.6.2012 (KH); 1 ex. - Bulgaria, Sandanski env., 31.5.2008 (KH); 2 ex. - RSFSR, Soči, 16.6.1990 (JCH); 1 ex. - Greece. Peloponnese, Lakonia nomos, Kelefa env., 26.-27.5.2003 (PJ); 5 ex. - Greece, Agio Theodori, 8.- 14.5.2013 (PJ); 2 ex. - Greece, Kalampaka, 8.-15.5.2013 (PJ); 5 ex. - Bulgaria, kemp YUG (5 km S Kiten), 24.6.2004 (PJ); 9 ex. - Russia, Orenburg reg., 16 km W Jasnyj, $330 \mathrm{~m}, 51^{\circ} 04^{\prime} \mathrm{N}$

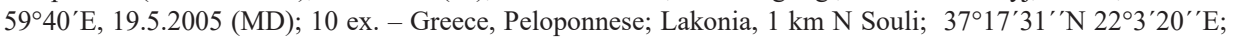
21.5.2018, $570 \mathrm{~m}$ (DN); 1 ex. - Greece, Peloponnese, Melissa bor., 8.- 20.4.1995 (PJ); 8 ex. - Greece Peloponnisos; Lakonia Fanaiti 1,5 km W; 31¹8'03“ N 2202’23“"E; 21.5.2018 (TL).

Body long, 6-13 mm, with metallic colour throughout, usually bluish green, blue to violet, rarely black, anterior part sometimes having metallic tint different from posterior part. Head with regular punctation, with interspaces larger than puncture diameter. Pronotum square-shaped or moderately longitudinal, moderately convex laterally, anteriorly somewhat more throttled than posteriorly, punctation denser than that on head, on disc moderately loosened anteriorly and moderately thickened posteriorly. Punctation not forming wrinkles. Male antennomeres exceeding body length by about one third, female antennomeres only slightly exceeding body, first antennomeres usually with distinct metallic tint, remaining ones only with moderate metallic tint. Antennae from the third article with distinct black eyebrows on inner side, sometimes whole antennae densely shortly white-haired, in some cases this light hair forms rings at base of antennomeres. In some cases antennae only entirely dark. Scutellum longitudinal, with very fine punctation, usually with pale pubescence. Elytra parallel, about 2.5 times longer than wide, with coarse punctuation weakening towards apical part. Head, prothorax and basal half of elytra with erect, rather long, black setae. Apical half of elytra with decumbent, black pubescence, without erect setae. Head sometimes with dense white pubescence. Legs with short, white pubescence. Body underside also metallic, covered with sparse, pale pubescence. Colour mostly greenish blue, sometimes only green, bright blue or elytra blue and pronotum green or anterior part black, remaining body area blue or violet.

Remarks: The most widely distributed species of the group Smaragdula. I do not exclude the occurrence of $A$. (S.) violacea in Armenia and Georgia, but in the material examined, I have not seen any specimens, which could be reliably identified as $A$. (S.) violacea. Only from Georgia, I know few specimens of $A$. (S.) persicola with completely or nearly reduced white pubescence of elytra, (see the next chapter). These specimens can resemble to $A$. (S.) violacea.

Given the broad polyphagy of specimens identified as $A$. (S.) violacea, in the otherwise narrowly foraging-specialized group Smaragdula, and the wider variation in characters, it is possible that this is a complex of cryptic taxa. For a detailed study of the taxon $A$. (S.) violacea, it would be necessary to collect a larger number of samples from across its range and possibly subject these samples to genetic analysis.

Bionomics: Imagines were found on Carduus, Centhranus, Medicago, Onobrychis, Psoralea, Phlomis, Salvia, Scabiosa, etc.

Agapanthia (Smaragdula) viti Rapuzzi \& Sama, 2012

(Figs.: 34, 56, 78, 117, 118)

viti Rapuzzi \& Sama, 2012: 675, Type locality: Hungary, Baks, 17.V.2003.

Geographic distribution: CR, HU, RO, SB, SK. 
Material examined: 21 ex. - Hungary, Vintyéd, ex larva, 15.III.2009 (KH);1 ex. - Hungary, Vintyéd, 25. IV.2009 (VS); 1 ex. - Slovakia, Kamenín, Kenínské slanisko NPR, 27.V.2012 (LK); 11 ex. - Hungary, Vintyéd, 12.6.2006 (PJ); 2 ex. PT - Slovakia mer. (8177), Kamenin; NPR Kam. Slanis., 20.5.2009 (OS).

Body length 12-15 mm. Species not very variable in colour, rather dark, obsoletely metallic blue green or with combination of these colours. Pronotum usually with three longitudinal stripes of pale pubescence. Pronotal punctation not forming wrinkles. With greyish white punctation of antennae usually forming narrow circles at bases of antennomeres. Scutellum usually with dense, yellowish pubescence. Elytra moderately narrowed towards apex, with dense punctation forming moderate wrinkles. Elytral punctation sometimes with slight indication of longitudinal ribs. Rather long, erect setae only at base, in first third, elytra otherwise with dense, yellowish pubescence. Body with yellowish pubescence also on ventral side. Presence of yellowish pubescence on elytra typical.

Remarks: It is a species similar to $A$. (S.) osmanlis, which can be differentiated based on the elytral pubescence colour: yellowish in $A$. (S.) vitti and white to greyish white in $A$. (S.) osmanlis. According to certain discussions belong the two taxa $A$. (S.) intermedia and $A$. (S.) vitti to be conspecific with each other. This could correspond to the absence of differences between larvae (Švácha, personal communication). However, in my opinions, these are unambiguously two different species, which corresponds not only to narrow nutritional preferences - Knautia in A. (S.) intermedia and Dipsacus laciniatus in $A$. (S.) vitti, but also to differences in male genitals.

Bionomics: The development occurs in Dipsacus laciniatus (Dipsacaceae). 


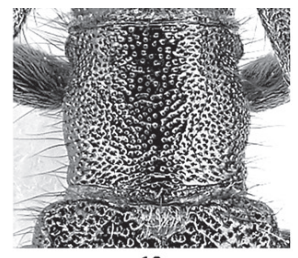

13

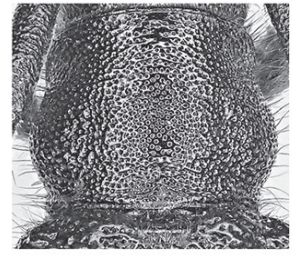

17

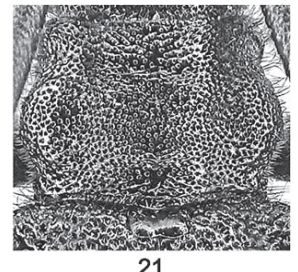

21

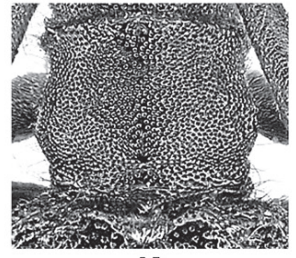

25

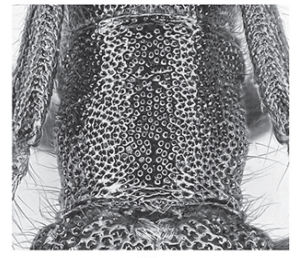

29

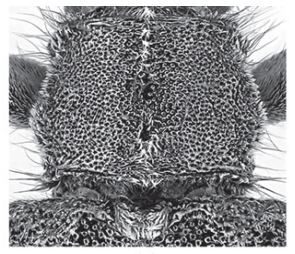

14

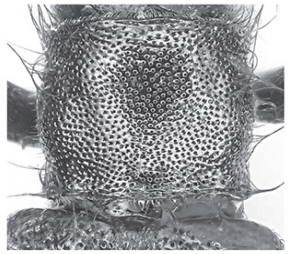

18
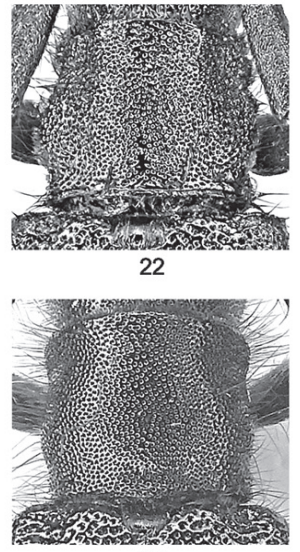

26

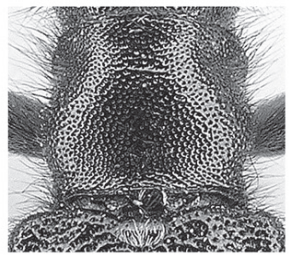

30

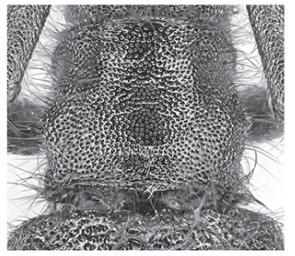

33

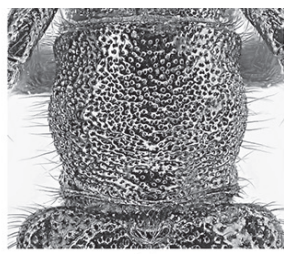

15

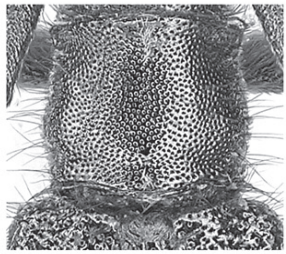

19

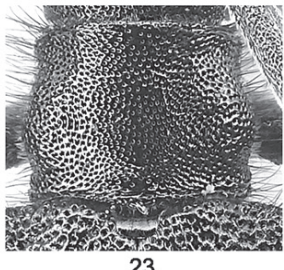

23

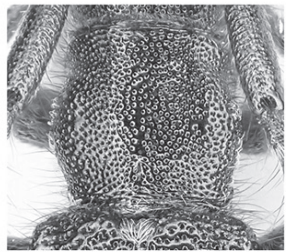

27

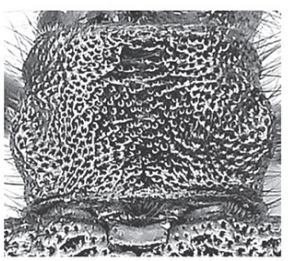

31

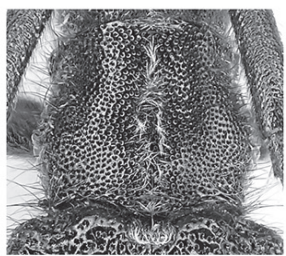

34

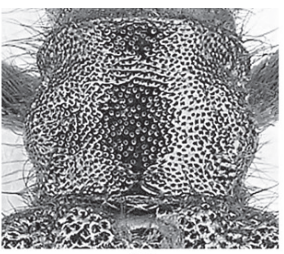

16

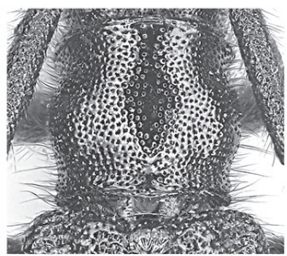

20

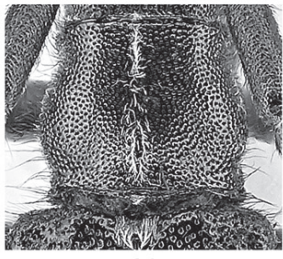

24

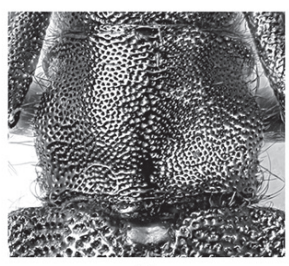

28

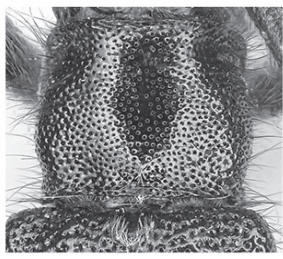

32

13 - A. (S.) amitina; 14 - A. (S.) chalybaea; 15 - A.(S.) frivaldszkyi; 16 - A. (S.) gemella; 17 - A. (S.) grosseri sp. nov.; 18 - A. (S.) incerta; 19 - A. (S.) intermedia; 20 - A. (S.) izzilloii; 21 - A. (S.) kadleci sp. nov.; 22 - A. (S.) lais; 23 - A. (S.) naciyae; 24 - A. (S.) osmanlis; 25 - A. (S.) ozdikmeni; 26- A. (S.) persicola; 27- A. (S.) pesarinii; 28 - A. (S.) petranyi; 29 - A. (S.) psoraleae; 30 - A. (S.) posti; 31 - A. (S.) rapuzzii; 32 - A. (S.) talassica; 33 - A. (S.) violacea; 34 - A. (S.) vitti 


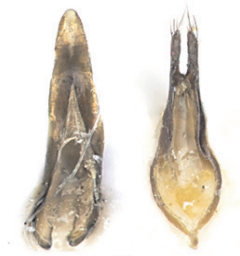

35

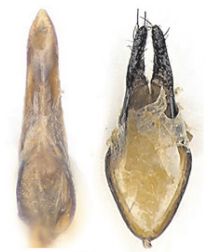

39

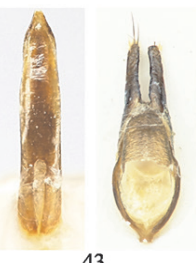

43

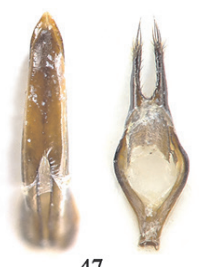

47

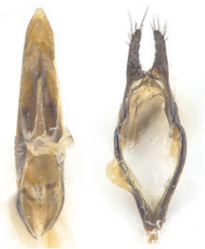

51

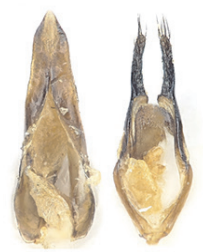

36

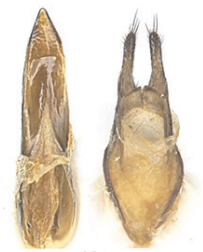

40

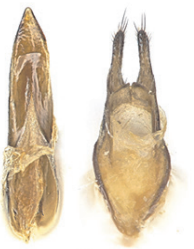

44

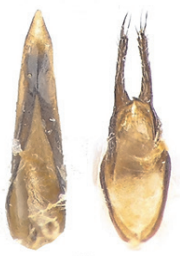

48

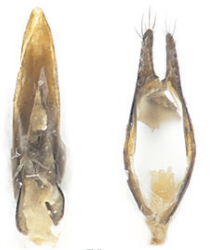

52

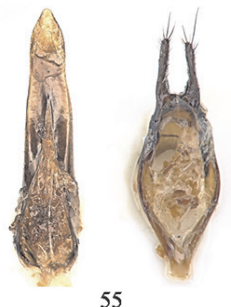

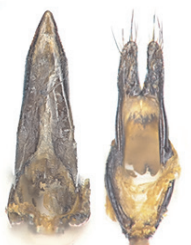

37

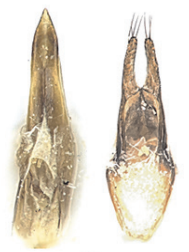

41

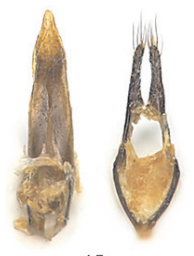

45

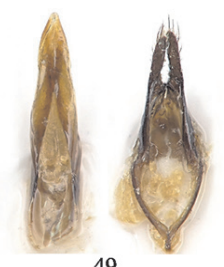

49

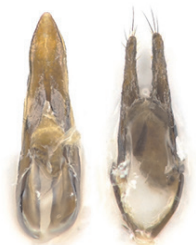

53

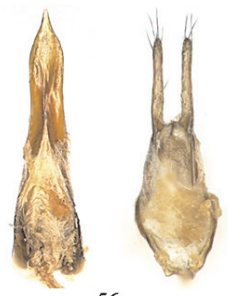

56

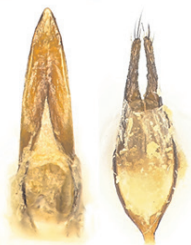

38
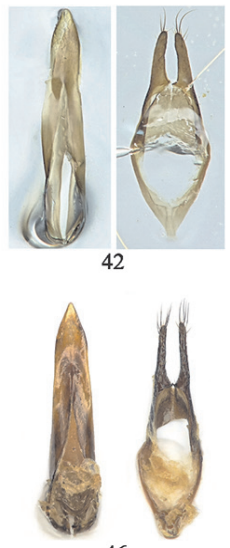

46

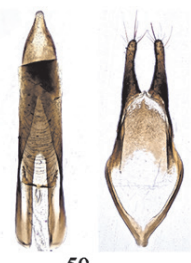

50

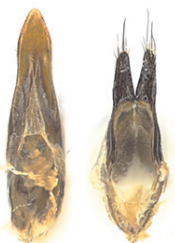

54

35 - A. (S.) amitina; 36 - A. (S.) chalybaea; 37 - A.(S.) frivaldszkyi; 38 - A. (S.) gemella; 39 - A. (S.) grosseri sp. nov.; 40 - A. (S.) incerta; 41 - A. (S.) intermedia;

42 - A. (S.) izzilloii; 43 - A. (S.) kadleci sp. nov.; 44 - A. (S.) lais; 45 - A. (S.) naciyae; 46 - A. (S.) asmanlis; 47 - A. (S.) ozdikmeni; 48 - A. (S.) persicola; 49 - A. (S.) pesarinii; 50 - A. (S.) petranyi; 51 - A. (S.) posti; 52 - A. (S.) psoraleae; 53 - A. (S.) rapuzzii; 54 - A. (S.) talassica; 55 - A. (S.) violacea; 56 - A. (S.) vitti 


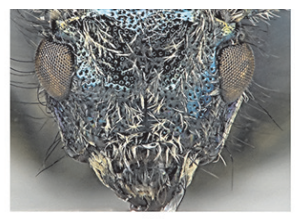

57

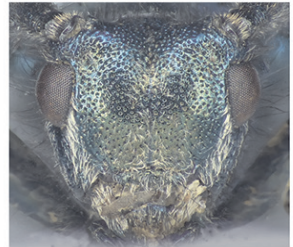

61

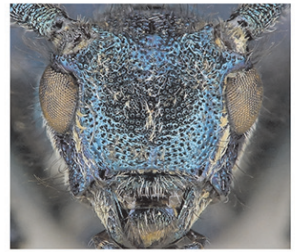

65

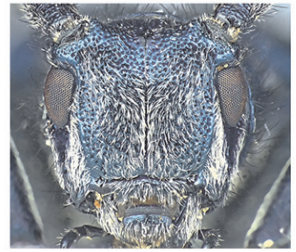

69

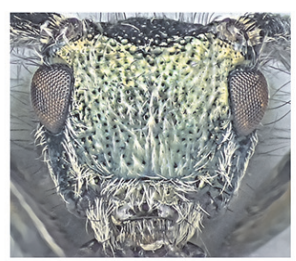

73

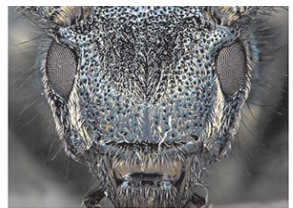

58

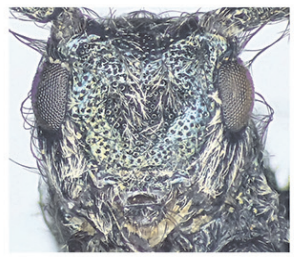

62

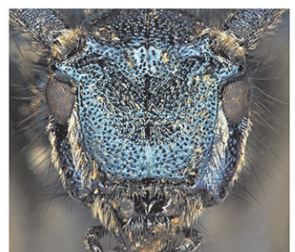

66

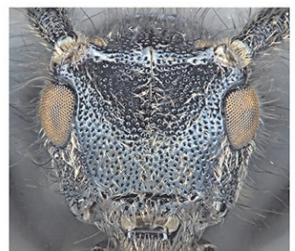

70

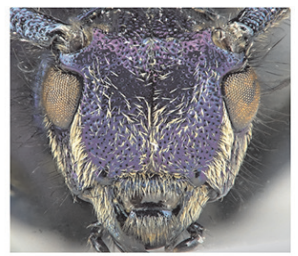

74

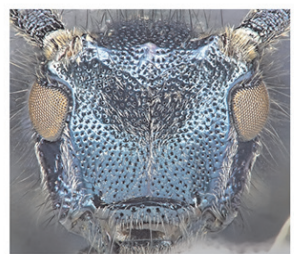

77

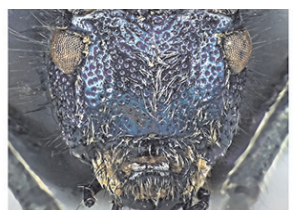

59

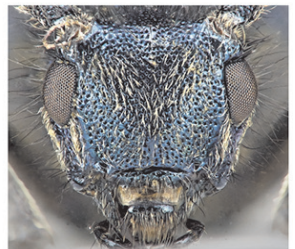

63

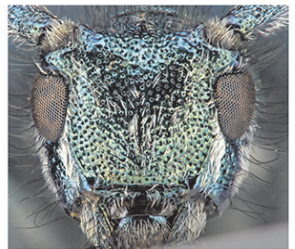

67

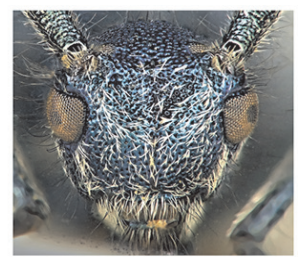

71

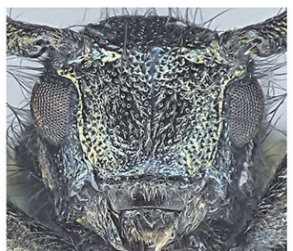

75

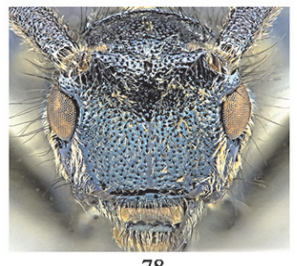

78

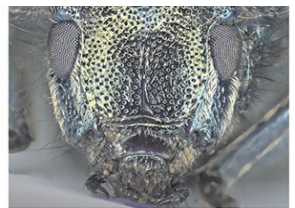

60

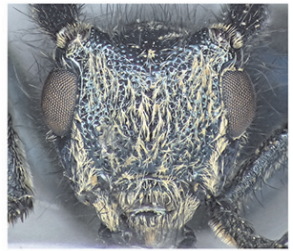

64

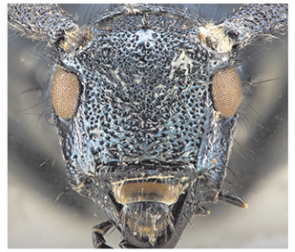

68

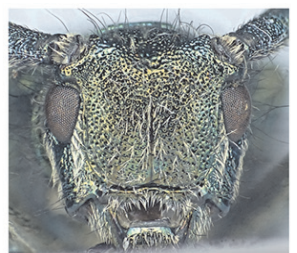

72

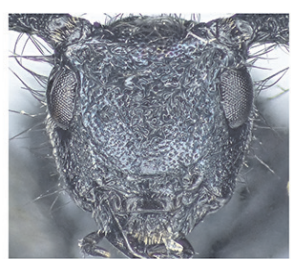

76

57 - A. (S.) amitina; 58 - A. (S.) chalybaea; 59 - A.(S.) frivaldszkyi; 60 - A. (S.) gemella; 61 - A. (S.) grosseri sp. nov.; 62 - A. (S.) incerta; 63 - A. (S.) intermedia; 64 - A. (S.) izzilloii; 65 - A. (S.) kadleci sp. nov.; 66 - A. (S.) lais; 67 - A. (S.) naciyae; 68 - A. (S.) osmanlis; 69 - A. (S.) ozdikmeni; 70 - A. (S.) persicola; 71 - A. (S.) pesarinii; 72 - A. (S.) petranyi; 73 - A. (S.) psoraleae; 74 - A. (S.) posti; 75 - A. (S.) rapuzzii; 76 - A. (S.) talassica; 77 - A. (S.) violacea; 78 - A. (S.) viti 

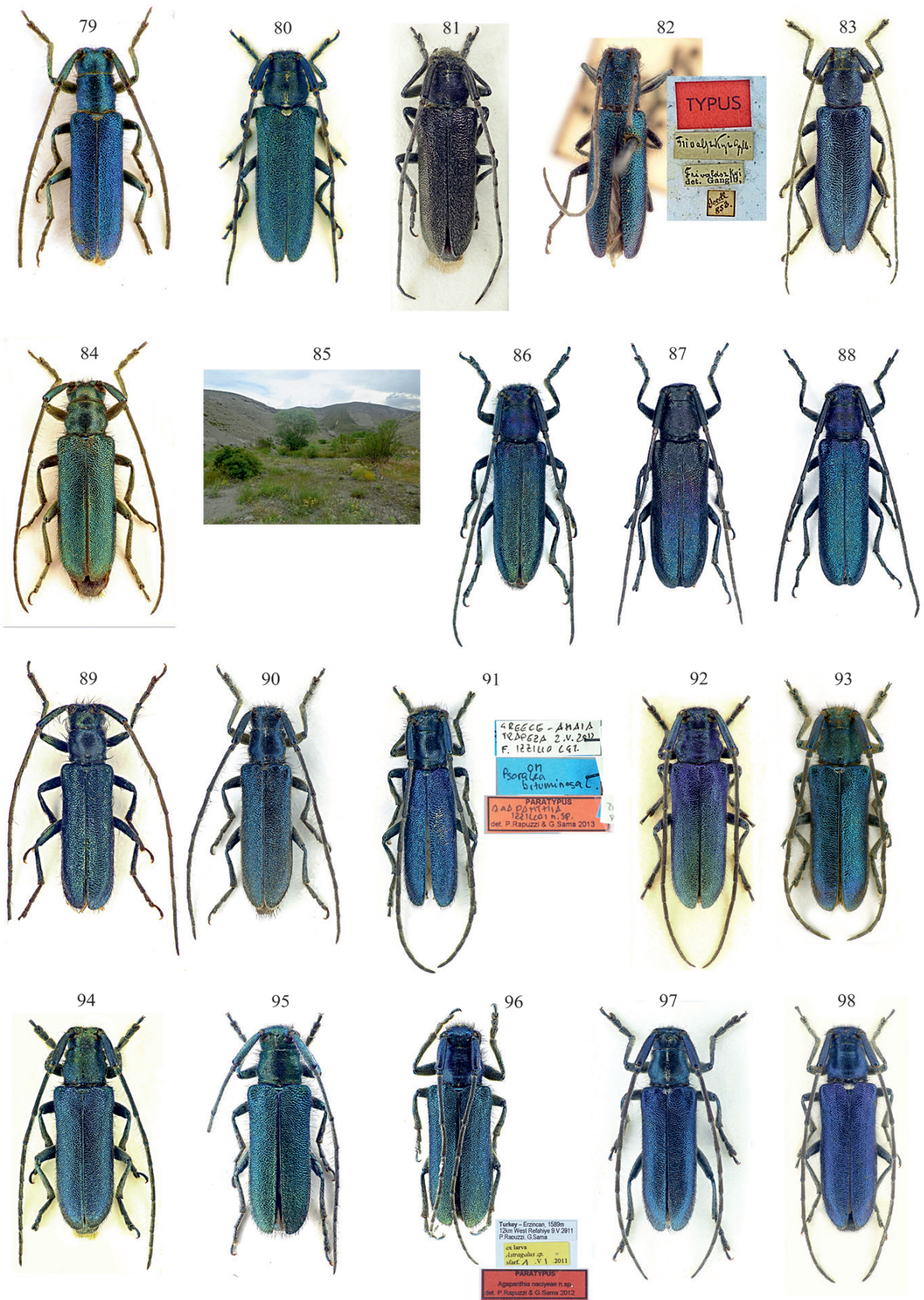

$79 \hat{\jmath}$ (PT) - A. (S.) amitina; 80 우, $81 \hat{\jmath}$ - A. (S.) chalybaea; $82 \hat{\jmath}$ (ST), 83 우 - A. (S.) frivaldszkyi; 84 우-A. (S.) gemella; 85 (type locality), $86 \hat{\jmath}$ (HT), 87 $ᄋ$ (PT), 88 q (PT)-

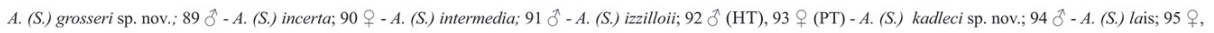



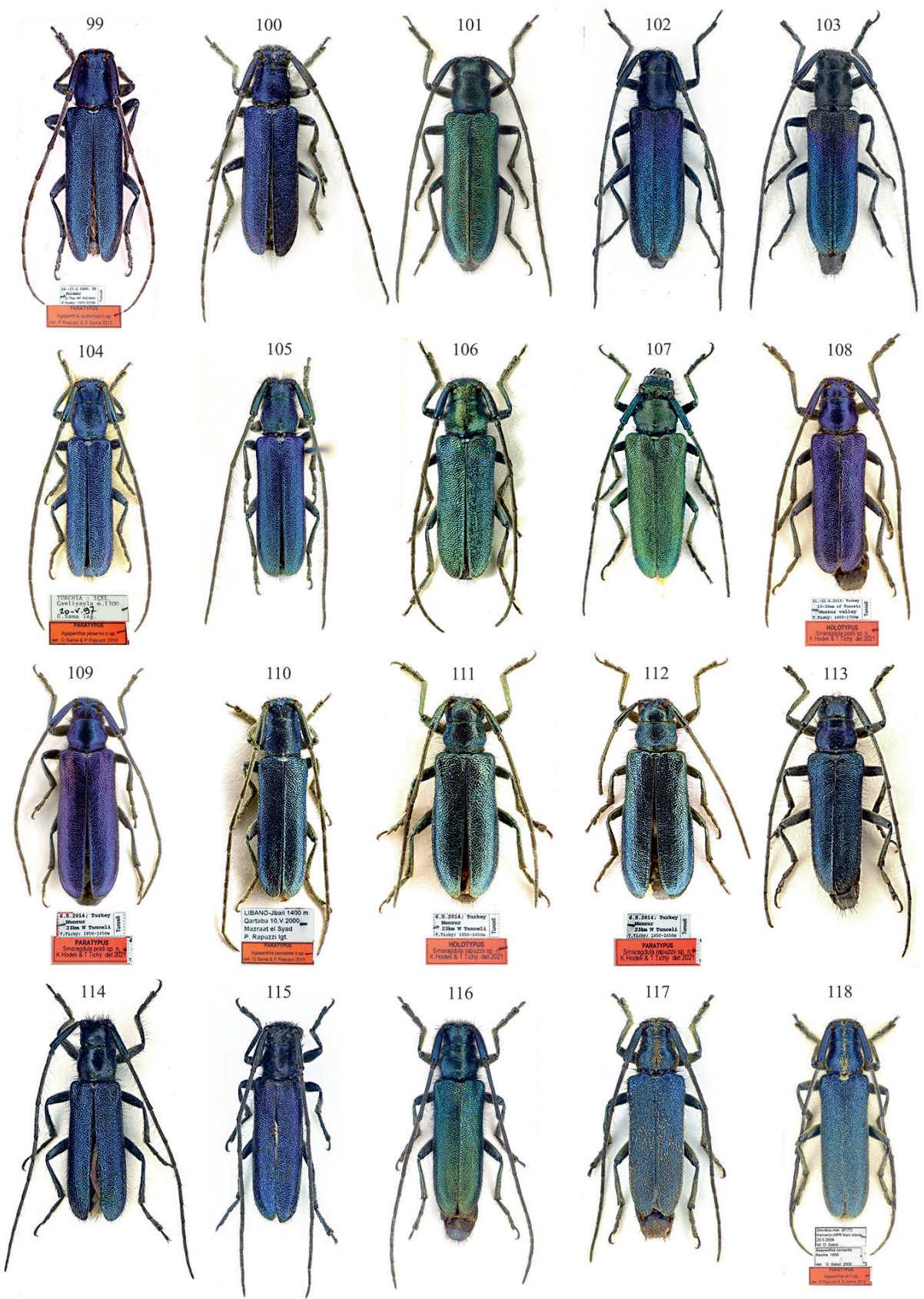


\section{Acknowledgements}

The author are very grateful to Národnímu Muzeum Praha represented by Lukáš Sekera, Tel Aviv University represented by Laibale Friedmann, Naturhistorisches Museum Wien represented by Harald Schilhammer, Mikhail Danilevsky (Moscow, Russia), David Navrátil (Litomyšl, Czech Republic), Josef Kadlec (Varnsdorf, Czech Republic), Lubomír Havlík (Polička, Czech Republic), Lukáš Skořepa (Dačice, Czech Republic), Matěj Čermák (Praha, Czech Republic), Petr Kabátek (Praha, Czech Republic), Pavel Štěpánek (Kladno, Czech Republic), Tomáš Peterka (Veselí nad Lužnicí, Czech Republic), Tomáš Tichý (Ostrava, Czech Republic), Pierpaolo Rapuzzi (Prepotto, Italy), Vladimír Skoupý (Kamenné Žehrovice, Czech Republic), Walter Grosser (Opava, Czech Republic), Ladislav Klapka (Česká Lípa, Czech Republic), Ondřej Konvička (Vsetín, Czech Republic), Zdeněk Košt'ál (Pardubice, Czech Republic), Pavel Jelínek (Brno, Czech Republic), Tomáš Lengál (Olomouc, Czech Republic), Ondřej Sabol (Ostrava-Nová Bělá, Czech Republic) for the loan of comparative material.

The author also thanks for comments on the Vítězslav Kubán̆ (Brno, Czech Republic) and Lukáš Bureš (Brno, Czech Republic), for information on Central Asian species ( $A$. (S.) talassica/incerta) Michail Danilevsky (Moscow, Russia), for help in the realization of this article Petr Zábranský (Vienna, Austria), for additional photos Luboš Dembický (Brno, Czech Republic) and for the translating Prof. Miloslav Rakovič DrSc. (Dobřichovice, Czech Republic).

Authors of photos: 85 - Walter Grosser (Opava, Czech Republic); 50, 107 - Luboš Dembický (Brno, Czech Republic); all the other photos - Karel Hodek (Brno, Czech Republic) 


\section{References}

Aurivillius, CH. 1923: Cerambycidae: Lamiinae. II., Coleopterorum Catalogus pars 74 [Vol. 23] II: 323-704. - W. Junk \& S. Schenkling, Berlin.

Brullé, A. G. 1832-1836: Expédition scientifique de Morée. Section des Sciences Physiques. Tome III. - 1.re Partie. Zoologie. Deuxième Section. - Des animaux articulés. F. G. Levrault, Paris 3 (1/2): 1-400, 52 pls., pp. 289-400 issued in 1833; plates in 1832-1836

Danilevsky, M. 2021: Catalogue of Paleartic Coleoptera Chrysomeloidea 1 (Vesperidae, Disteniidae, Cerambycidae) Updated and Revised Second Edition, 6/1.

FAbricius, J. CH. 1775: Systema Entomologiae, sistens insectorum classes, ordines, genera, species, adiectis synonymis, locis, descriptionibus, observationibus, Officina Libraria Kortii; Flensburgi \& Lipsiae $30+$ $832 \mathrm{pp}$.

FABRICIUS, J. CH. 1801: Systema eleutheratorum secundum ordines, genera, species : adiectis synonymis, locis, observationibus, descriptionibus, Bibliopoli Academici Novi, Kiliae 2: 1-687.

Faldermann, F. 1837: Fauna entomologica Transcaucasica. Coleoptera 2. Longicornes vel Capricornes. Nouveaux Mémoires de la Société Impériale des Naturalistes de Moscou 5: 1-433, 15 pls. (pls VII-XI)

FrIESER, R. 1976: Cerambycidenstudien (Col. Cerambycidae), Nachrichtenblatt der Bayerischen. - Entomologen 25 (3): 43-44. 15 juin 1976

Fuesslins, J. C. 1775: Verzeichniss der ihm bekannten Schweizerischen Insecten. - Verfasser, Zürich 4: i-xii $+1-62,1$ pl. couleur

Ganglbauer, L. 1884: Bestimmungs-Tabellen der europäischen Coleopteren. VIII. Cerambycidae. (Schluss.) Mit Berücksichtigung der Formen Algiers und des paläarktischen Asiens, exclusive jener von Japan. Verhandlungen der kaiserlich-königlichen zoologisch-botanischen Gesellschaft in Wien 33 [1883]: 437586, 2 figs.

Gianfranco, S., Rapuzzi, P. \& Kairouz, A. 2010: Catalogue commenté des Cerambycidae du Liban. An annotated catalogue of the Cerambycidae of Lebanon (Insecta Coleoptera Cerambycidae). - Quaderni di Studi e Notizie di Storia Naturale della Romagna 30: 131-201.

Gmelin, J. F. 1790: Caroli a Linné Systema Naturæ per Regna tria Naturae, secundum Classes, Ordines, Genera, Species, cum characteribus, differentiis, synonymis, locis. Classis V. Insecta, Editio 13. - Lipsiae, Georg Emanuel Beer 1(4): 1517-2224.

Herbst J. F. W. 1784: Kritisches Verzeichniß meiner Insektensammlung, Archiv der Insectengeschichte 5(1): 1-151, pls XIX-XXX. - Zürich und Winterthur, H. Steiner \& Comy

HeYrovský, L. 1943: Tři nové odrůdy tesaříků. Drei neue Cerambyciden aberrationen. - Časopis České Společnosti Entomologické, Praha 40(1-2): 50-51.

Hodek, K. \& TichÝ, T. 2021: Two new species of Agapanthia (Smaragdula) Pesarini \& Sabbadini, 2004 from Turkey (Coleoptera: Cerambycidae: Lamiinae). - Studies and Reports Taxonomical Series 17(1): 29-36.

HolzschuH, C. 1989: Beschreibung neuer Bockkäfer aus Europa und Asien (Cerambycidae, Col.). Koleopterologische Rundschau 59: 153-183.

Kotán, A. 2014: A new species of Agapanthia Audinet-Serville, 1835 from Iran (Coleoptera, Cerambycidae: Lamiinae). - Folia Entomologica Hungarica 75: 63-68.

KRYNICKI, J. 1832: Enumeratio Coleopterorum Rossiae meridionalis et praecipue in Universitatis Caesareae Charkoviensis circulo obvenientum, quae annorum 1827-1831 spatio observavit. - Bulletin de la Société Impériale des Naturalistes de Moscou 5: 65-179, pls II-III.

Küster, H. C. 1846: Die Käfer Europa's. Nach der Natur beschrieben. - Mit Beiträgen mehrerer Entomologen, Nürnberg, Bauer \& Raspe 6: n 1-100, 2 pls., juillet 1846

Löbl, I. \& Smetana, A. 2010: Catalogue of Paleartic Coleoptera. 6. Chrysomeloidea. - Apollo Books, Stenstrup: $924 \mathrm{pp}$.

Mulsant, É. 1839: Histoire Naturelle des Coléoptères de France. Longicornes. Paris, Maison : vii-xii + 1-304 pp., 3 pls.

Mulsant, É. 1862: Histoire Naturelle des Coléoptères de France. Longicornes. - Annales de la Société Impériale d'Agriculture, d'Histoire Naturelle et des Arts Utiles de Lyon 1862: 1-480.

Özdikmen, H. 2013: Turkish Agapanthiini Mulsant, 1839 with identification keys (Coleoptera: Lamiinae). Munis Entomology \& Zoology 8(1): 9-37.

Pesarini, C. \& SAbBadini, A. 2004: Osservazioni sulla sistematica della tribu Agapanthiini Mulsant, 1839 (Coleoptera Cerambycidae). - Atti della Società Italiana di Scienze Naturali e del Museo Civico di Storia Naturale Milano 145: 117-132. 
Pesarini, C. \& Sabbadini, A. 2007: Notes on some Longhorn beetles from Continental Greece, with description of two new subspecies (Coleoptera: Cerambycidae). - Atti della Società Italiana di Scienze Naturali e del Museo Civico di Storia Naturale in Milano 148(1): 17-34.

PIC, M. 1904: Descriptions de divers Longicornes d'Europe et d'Asie, Matériaux pour servir à l'étude des Longicornes 5(1): 7-9.

Plavilstshikov, N. N. 1930: Die Agapanthia-Arten der paläarktischen Region. - Bestimmungs-Tabellen der europäischen Coleopteren, Troppau 98: 1-40.

Plavilstshikov, N. N. 1930: Die Agapanthia-Arten der paläarktischen Region. - Bestimmungs-Tabellen der europäischen Coleopteren, Troppau 98: 1-40.

RApuzZi, P. \& SAMA, G. 2012: New taxa and new records of Longhorn-Beetles from Eastern Mediterranean Region (Coleoptera: Cerambycidae). - Munis Entomology \& Zoology 7(2): 663-690.

Reitter, E., Mik, J. \& WachtL, F. A. 1894: Wiener Entomologische Zeitung, Jahrg.13

Sama, G., Buse, J., Orbach, E., Friedman, A. L. L., Rittner, O. \& Chikatunov, L. 2010: A new catalogue of the Cerambycidae (Coleoptera) of Israel with notes on their distribution and host plants - Munis Entomology \& Zoology 5(1): 1-49.

SCHÖNHERR, C. J. 1817: Synonymia insectorum, oder: Versuch einer Synonymie Aller bisher bekannten Insecten ; nach Fabricii Systema Eleutheratorum \&:c. geordnet, Skara, Lewerentzischen Buchdrükerey 1 (3): $\mathrm{xi}+1-506$.

Sláma, M. E. F. 1998: Tesaříkovití - Cerambycidae České republiky a Slovenské republiky (Brouci Coleoptera). - Milan Sláma 384 pp.

Švácha, P. \& Klausnitzer, B. 2001: Die Larven der Käfer Mitteleuropas, 6. Band Polyphaga, Teil 5, 1175 Abbildungen, Berlin

Tavakilian, G. (Author), Chevillotte, H. (Software). 2018: Base de données Titan sur les Cerambycidés ou Longicornes. [20/12/2018]. [http://titan.gbif.fr/index.html].

VILliers, A. 1967: Contribution à la faune de l'Iran. I. - Coléoptères Cerambycidae. - Annales de la Société Entomologique de France (N.S.) 3 (2): 327-379. 